\title{
AVALIACAO DO COMPORTAMENTO DE BEZERROS LEITEIROS LACTENTES E DESMAMADOS, EM BAIAS INDIVIDUAIS E COLETIVAS
}

\author{
MARISTELA NEUES DA CONCEICAO \\ Engenheiro agronomo
}

Orientador: Prof. Dr. Vidal Pedroso de Faria

Diesertacao
Escola superior apresentada
"Luiz de Agricultura
Universidado de sao Paulo, para
obtencao do titulo de mostro om
Agronomia, Area de Concentracao:
Nutricao Animal o Pastagons.

\section{PIRACICABA}

Estado de Sao Paulo - Brasil

Janeiro - 1991 
Ficha catalográfica preparada pela Seção de Livros da Divisão de Biblioteca e Documentação - PCAP/USP

\footnotetext{
Conceição, Maristela Neves da

C744a Avaliação do comportamento de bezerros leiteiros lactentes e desmamados, em baias individuais e cole tivas. Piracicaba, 1991.

$72 \mathrm{p}$.

Diss. (Mestre) - ESALQ

Bibliografia.

1. Baia para bezerro leiteiro - Manejo 2. Bezerro leiteiro - Comportamento 3. Bezerro leiteiro Criação I. Escola Superior de Agricultura Luiz de Queiroz, Piracicaba
} 


\title{
AVALIACÃ̃O DO COMPORTAMENTO DE BEZERROS LEITEIROS LACTENTES E DESMAMADOS, EM BAIAS INDIVIDUAIS E COLETIVAS
}

\author{
MARISTELA NEUES DA CONCEICÃ̃o
}
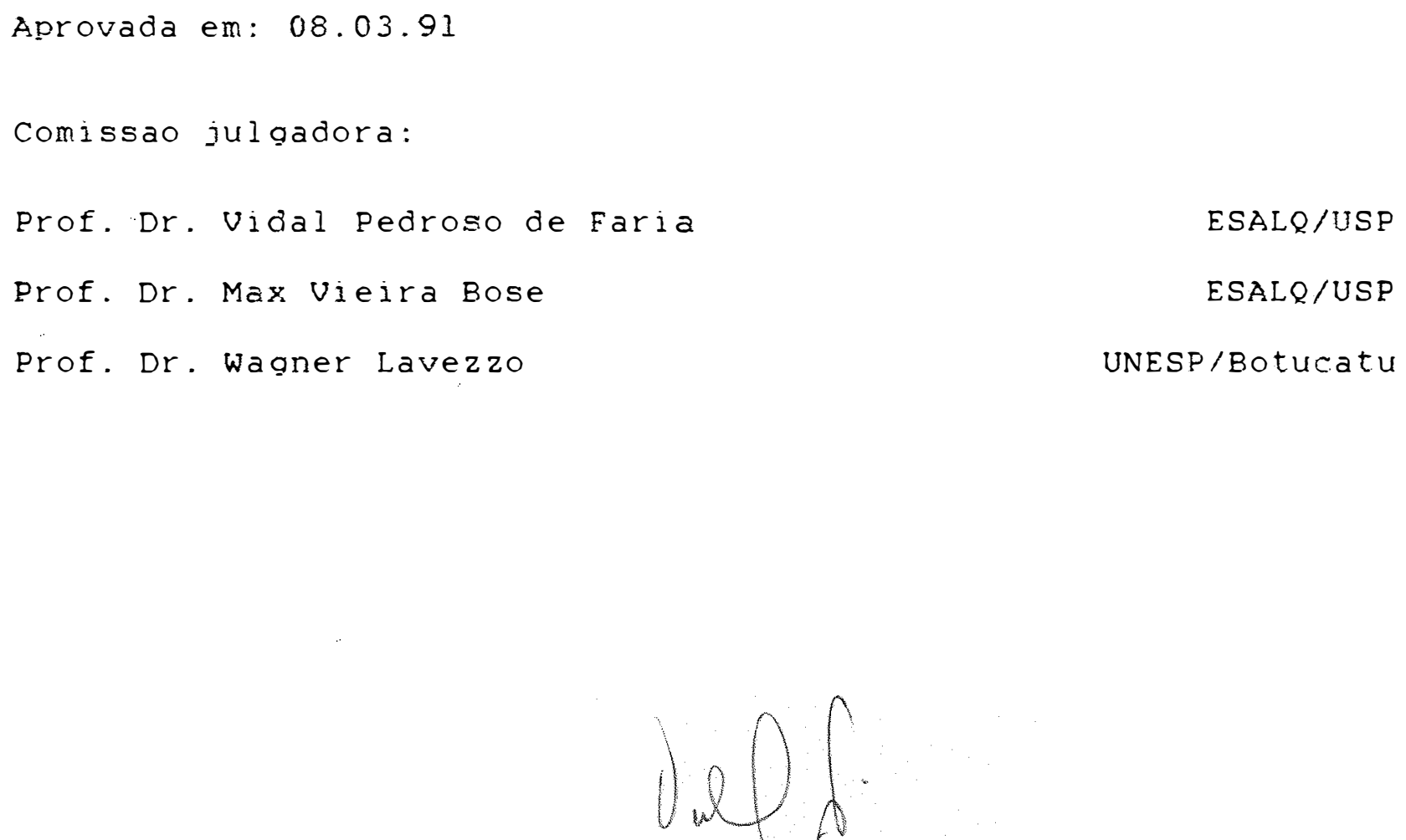

Prof. Dr. Vidal pedroso de Faria ORIENTADOR 
Aos meus pais, Ezequiel e Maria Rosa.

Aos meus irmas, Quee1, N1, Be e De, grandes companheiros de bons e maus momentos, 
Aos companheiros do curso de pos graduacao pela companhia e amizade.

A Fundacao Faculdade de Agronomia "Luiz Meneqhel" pela cessao de equipamentos e auxilio na elaboracao final do trabalho.

Ao Amadeu, porque ele existe.

Enfim a todos os que ajudaram. das mais diversas formas, meu muito obrigada.

Aqueles que nao ajudaram por falta de oportunidade meus tambem sinceros agradecimentos.

E dqueles que prejudicaram por ignorancia ou descaso, o desejo de que nao se confrontem com situacoes semelhantes. 


\section{AORADECIMENTOS}

Ao Professor vidal Pedroso de Faria, pela orientacao e amizade.

Ao Professor Max Lazaro Bose por se prontificar, de tao boa vontade a fazer as ultimas correcos do trabalho.

A Fundacao de Amparo a Pesquisa do Estado de sao Paulo, pela bolsa de estudos concedio.

A Fazenda Pinhalzinho que gentilmente cedeu os animais utilizados no experimento.

A Engenheira Agronoma Patricia Claudia Marin, grande amiga, cujo auxlijo garantiu a elaboraca do trabalho.

Ao amigo e companheiro Paulo Jose Hamakawa, pelo constante apoio e pela elaboracao do programa de computador que permitiu a compilacao dos dados obtidos.

A todos os funcionarios do Depto de zootecnia da ESALo, particularmente aos srs. Evildsio de Camargo e Joso Ladeira viana, pela grande colaboraca no manejo com os animais.

Aos estagarios do clube de praticas zootecnicas (CPZ), pela ajuda na conduca do experimento.

Aos demais professores do Depto de Zootecnia da ESALQ, pela contribuicao na minha formacao profissional. 


\section{BUMARIO}

pdgina

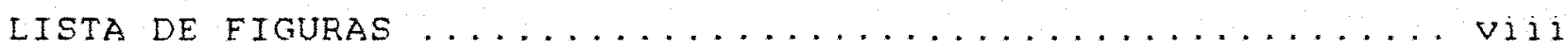

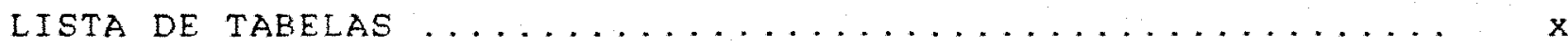

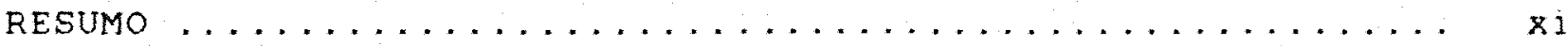

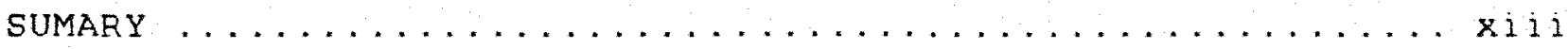

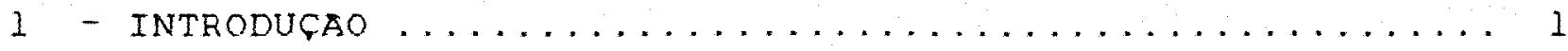

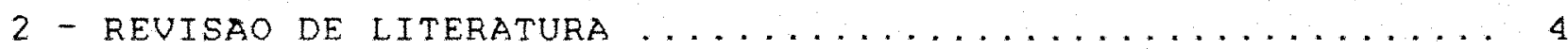

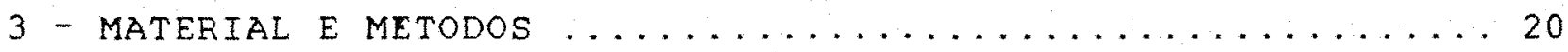

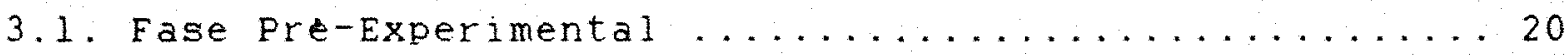

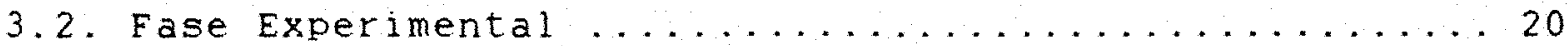

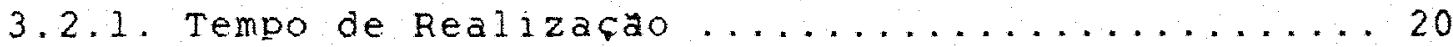

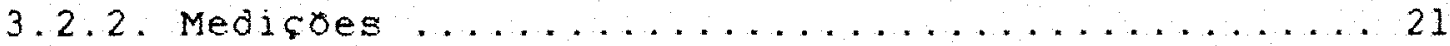

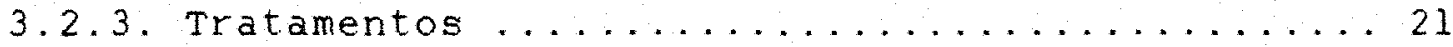

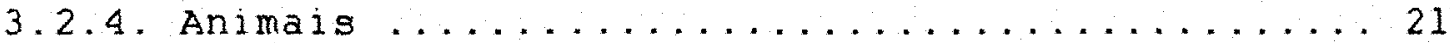

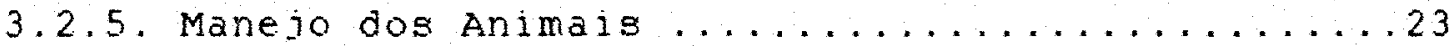

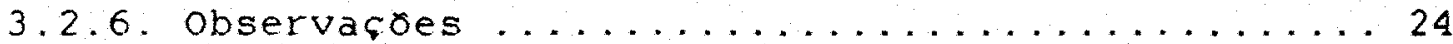

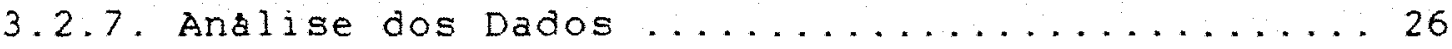

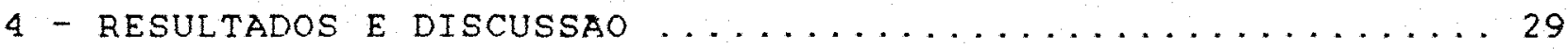

4.1. Temperatura e Umidade ................... 29

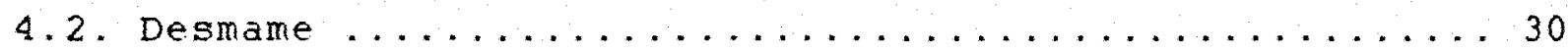

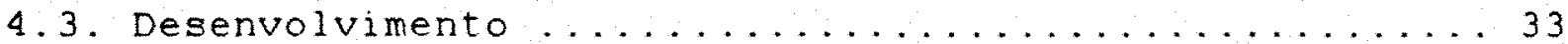

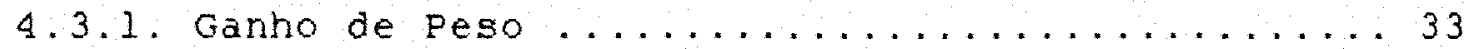

4.3 .2 ocorrencia de Doencas .........................

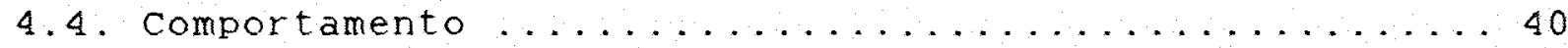

4.4.1. Alteracoes nas posicoes em pe e deitados ....40 40

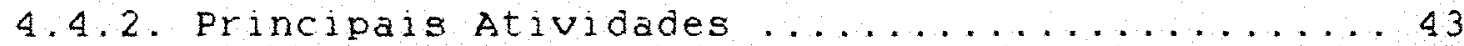

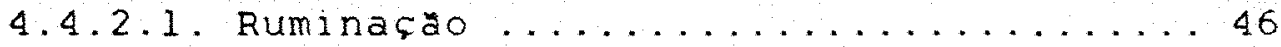

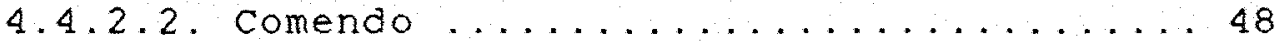

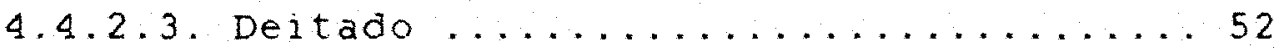

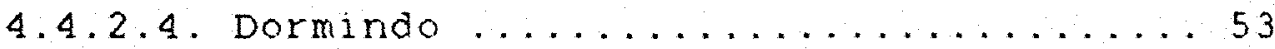

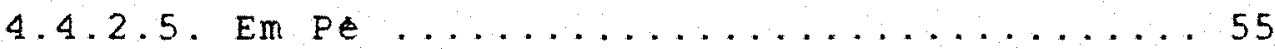

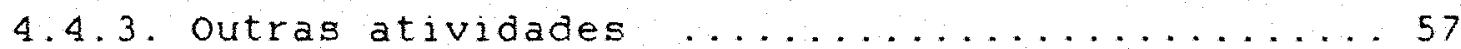

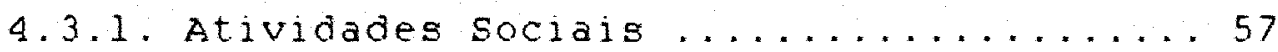


$5-$ CONCLUSOES .............................. 64

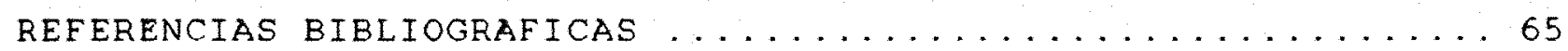

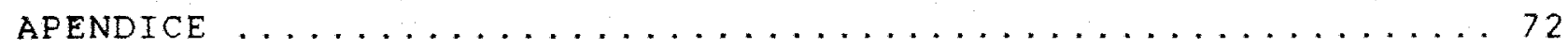




\section{LIBTA DE FIOURAB}

01 - Esquema de baias usadas no trabalho experimental ..... 22

02 - Desenvolvimento dos animais, nos dois tratamentos, a partir da terceira semana ate

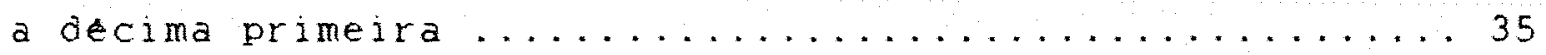

03 - Consumo de racao concentrada, em ambos os tratamentos, a partir da terceira semana de idade ate a decima primeira ....................

04 - Tempo que os animais permaneceram em pe durante o dia desenvolvendo qualquer atividade $\ldots \ldots \ldots \ldots \ldots \ldots$

05 - Numero de vezes que os animais levantaram no dia . . . . 43

06 - Tempo gasto nas principais atividades pelos animais nas baias individuais $\ldots \ldots \ldots \ldots \ldots \ldots \ldots$

07 - Tempo gasto nas principais atividades pelos animais nas baias coletivas .................45

08 - Tempo que os animais passaram ruminando durante o

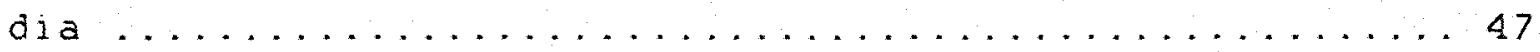

09 - Numero de vezes que os animais ruminaram .........48

10 - Tempo que os animais passaram alimentando-se .......5 50

11 - Numero de vezes que os animais se alimentaram no

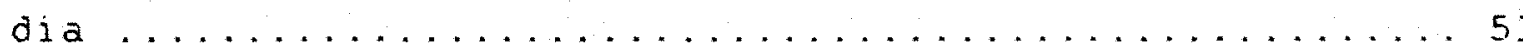


12 - Tempo que os bezerros passaram deitados sem desenvolver qualquer outra atividade $\ldots \ldots \ldots \ldots \ldots \ldots$

13 - Tempo que os animais dormiram durante o dia ........ 55

14 - Tempo que os animais ficaram em pe sem desenvolver qualquer atividade $\ldots \ldots \ldots \ldots \ldots \ldots \ldots \ldots \ldots \ldots \ldots$

15 - Tempo que os animais passaram andando ........... 58

16 - Numero de vezes que os animais olharam para fora

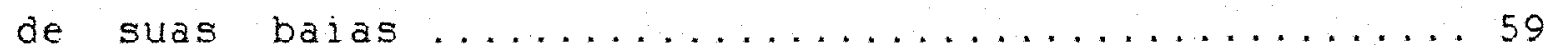

17 - Tempo que os animais passaram sugando ............6 60

18 - Numero de vezes que os animais sugaram ...........61

19 - Tempo que os animais passaram lambendo ...........62

20 - Numero de vezes que os animals se lamberam, lamberam o companheiro ou objetos $\ldots \ldots \ldots \ldots \ldots \ldots$ 


\section{LISTA DE TABELAS}

pogina

01 - Idade e peso dos animais no inicio do periodo experimental ...................... 23

02 - Dados meteorologicos dos dias em que foram feitas as observacoes e do dia imediatamente anterior ........ 29

03 - Idade, peso e consumo de concentrado por ocasido da desmama ............................. 30

04 - Analise de variancia para a idade e peso dos animais por ocasiao do desmame $\ldots \ldots \ldots \ldots \ldots \ldots \ldots \ldots$

05 - Peso dos animas (kg) aos 17 dias e aos 76 dias, consumo total de concentrado (Kg) e ganho de

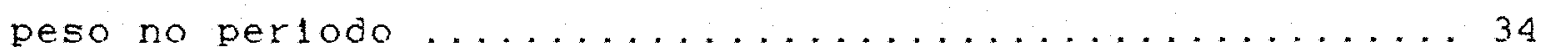

06 - Casos de febre, diarreia e numero de medicacoes durante o periodo experimental .................. 38

07 - Andise de variancia para o tempo total que os animais permaneceram em pe durante o dia ..........4 42

08 - Percentagem do tempo gasto nas principais atividades diarias nas Baias Individuais . . . . . . . . 44

09 - Percentagem do tempo gasto nas principais atividades didrias nas Raias coletivas .............44 


\title{
AVALIACAO DO COMPORTAMENTO DE BEZERROS LEITEIROS LACTENTES E DESMAMADOS, EM BAIAS INDIVIDUAIS E COLETIVAS.
}

\author{
Autora: MARISTELA NEVES DA CONCEICAO \\ Orientador: PROF. DR. VIDAL PEDROSO DE FARIA
}

RESUMO

o presente experimento foi realizado na Escola superior de Agricultura "Luiz de Queiroz", no Departamento de zootecnia, e teve como objetivo o estudo do comportamento de bezerros da raca holandesa preta e branca, criados em baias individuais e coletivas, visando estabelecer condiçoes de manejo que racionalizem gastos com instalaçoes e máo de obra. Foram observados 12 animais com idades iniciais de tres semanas, sendo 06 colocados em baias individuais e 06 em baias coletivas. As observaçoes foram feitas semanalmente, durante 24 horas consecutivas totalizando 10 semanas e todas as atividades comportamentais foram anotadas. A alimentacáo dos bezerros constituiu-se de leite integral $42 / d i a$, feno de capim de rhodes á vontade e raça concentrada, cujo consumo foi determinado diariamente. Os animais foram pesados semanalmente para que se estabelecesse uma curva de crescimento médio nos dois tratamentos: O desaleitamento foi feito observando-se o aspecto geral dos animais. Por ocasiáo do desmame, o consumo de racäo concentrada era em média $1,0 \mathrm{~kg} / \mathrm{cab} / \mathrm{dia} e$ os animais tinham em média 45,7 dias nas baias individuais e 54 dias nas coletivas. As principais atividades comportamentais observadas foram analisadas graficamente. Determinou-se o tempo dispendido pelos animas em 
cada atividade e o numero de vezes que cada atividade foi desenvolvida. As atividades analisadas foram: ruminaça, alimentacáo, repouso deitado, dormir, repouso em pé e atividades sociais. A percentagem do tempo diario que os animais passaram ruminando, alimentando-se, repousando, dormindo, em pé e em atividades sociais, nas baias individuais foram, respectivamente: $15,48,12,08,37,0 \%, 18,08,5,48$ e $12,1 \%$ e nas baias coletivas foram: $18,2 \%, 14,8 \%, 31,0 \%, 18,3 \%, 6,69 \%$ e $10,8 \%$ o trabalho demonstrou náo haver diferencas acentuadas nas atividades comportamentais de bezerros criados em baias individuais ou em baias coletivas. Ambos os sistemas de criaça mostraram-se satisfatórios, haja visto o desenvolvimento ponderal dos animais. 


\title{
BEHAVIOR EVALUATION OF MILK-YIELDING, UNWEANED AND WEANED CALVES IN INDIVIDUALS PENS AND GROUP REARED
}

\author{
Author:MARISTELA NEUES DA CONCEICÃO \\ Adviser: PROF. DR. VIDAL PEDROSO DE FARIA
}

SUMMARY

This experiment was carried out at Escola superior de Agricultura "Luiz de Queiroz", Departamento de zootecnia and aimed to study the behavior of holstein calve spet in different rearing systens: individuals pens and in group pens. The purpose was stdy manegement conditions and less expensives cattle facilities and hand labor. In the beggining of experiment calves were three weeks old. Six of then were put in inoividuals pens and the other six in group pens. Observation were made 24 hours a day for a 10 week period. During this time activities to study behavior were registered. Calves were fees $4 \mathrm{Kg}$ of whole milk per day, rhodes grass hay "ad libitum" and a comercial grain misture for calves. Intake was determined each day. Animals were wheigthed weekly and the data used to draw a growth curve for each treatment. Weanıno was in acordance with the general aspect of the animals. At this time animals ate $1,0 \mathrm{~kg}$ of concentrated per day and were sepet for 45,7 days in individuals pens and 54 days in group pens. The main activities registered were analysed graphically. It was determined how long each activity last and how many times each activity was repeated. Activies analysed were: 
xiv

rumination, feeding, lying, sleeping, standing and social activities. Time fractions of the day expressed in percentage, spent on each of the analysed activities, in individual pens were: $15,48,12,08,37,0 \%, 18,08,5,48$ and $12,1 \% ;$ in group reared correspondents values were: $18,28,14,8 \%, 31,0 \%, 18,38,6,698$ and 10.8\%. This experiment showed no marked differences in behavior activities of calves both in individuals or in group pens and that considering the development of the animals both rearing systems were equal. 


\section{INTRODUCAOO}

Estudos antropologicos demonstraram que o homem, inicialmente herblvoro, com o decorrer da evoluca tornou-se onivoro. Esta alteraca nos habitos alimentares deu-se provavelmente devido a buscas de fontes proteicas que, em menor quantidade, fornecessem aminodcidos essenciais melhor balanceados, como a carne. Este alimento, obtido inicialmente de forma predatoria, passou, com o correr do tempo, a ser obtido atraves da criacao e abate de certas especies animais. Iniciou-se uma relacao, de certa forma, simbiotica entre o homem e os animais, que hoje recebe o nome de domesticaca.

Sem exceca, todas as especies domesticas de importancia economica sao animajs de habitos sociais (BANKS, 1982), o que concorreu para facilitar a domesticaca, uma vez que os animais ja viviam em grupos no seu estado natural. Com a tendencia crescente em direcáo ao confinamento de animais mais produtivos, torna-se premente a necessidade do conhecimento do comportamento animal.

Sequndo Lorenz, citado por JoHnsGaRd (1973), considerado - pai da moderna etologia, o animal nao age somente por instintos, mas responde a estimulos internos e externos que o levam a assumir determinados comportamentos. Sua teoria era de que conhecendo estes estimulos seria posslvel controlar melhor os animais. com a necessidade cada vez maior de alimentos e a 
disponibilidade cada vez menor de terras as tecnicas de criacao animal foram aprimoradas para que pudessem competir. em termos de iqualdade, com a aqricultura. O confinamento de animas mais produtivos e um reflexo desta necessidace e o estudo do comportamento torna-se cada vez mais importante neste contexto.

KILgOUR (1978) citou que a impossibilidade de uma aplicasao imediata do estudo do comportamento animal tem releoado - mesmo a um sequndo plano. CURTIS \& HOUPT (1983) relataram que a partir de 1972 , em apenas duas publicacoes foram divulgados 330 trabalhos sobre comportamento, mas comentaram, que mesmo assim, o conhecimento neste campo ainda e restrito.

Conhecimentos sobre habitos alimentares em pastagem ou cocho, comportamento social ou sexual, indicacao de estresse, bem estar animal, habilidade materna, etc..., sao necessarios para que a produca animal possa ser incrementada atraves de uma concepca de instalacoes e tecnicas de manejo mais eficientes. Estudos feitos com galinaceos mostraram a veracidade desta afirmacao, uma vez que as galinhas foram transformadas em verdadeiras maquinas de producao de carne e ovos.

No Brasil, a cada ano cresce o interesse por este campo. Cursos sobre etologia tem sido organizados com uma certa frequencia. Trabalhos tem sido publicados nas mais diversas areas de concentraca, a ponto de se realizar anualmente um "Encontro Nacional de Etologia". O presente trabalho procura avaliar as alteracoes comportamentais de bezerros lejteiros no decorrer da idade e determinar a influencia do tipo de baia (individual ou 
coletiva) sobre o comportamento, visando possiveis alteracoes no manejo que venham a racionalizar gastos com instalacres e mao de obra. 


\section{REVIBAO DE LITEAATURA}

- estudo do comportamento animal e uma ciencia relativamente nova, com bases e princlpios ainda nao totalmente claros. Darwin, com sua teoria da evoluca, em seu classico livro "Expression of the emotions of man and animal", publicado em 1872, foi sem duvida o responsavel pelo suraimento desta ciencia. No entanto, o estudo de comportamento animal propriamente dito, iniciou-se com Julian Huxley e H. Eliot Howard na Alemanha, onde mais tarde Heinroth's popularizou o termo Etologia, e onde K. Lorenz, seu discipulo, expos as ideias em forma de teoria numa publicacao em 1930 (JOHNSGARD, 1973). MANNING (1972) citou que o intcio dos estudos sobre o comportamento deu-se nos E.U.A. com O livro "Behaviorism", publicado em 1924 por J.B. Watson. Ambos os autores concordam que - estudo do comportamento no mundo ficou dividido em duas escolas: a europeia constitulda por etologistas, para os quais o termo etologia significava estudo cientifico do comportamento, e a escola americana, constituloa principalmente por biolooos e psicologos, para os quais o estudo do comportamento animal auxiliaria no conhecimento do ser humano.

Devido a complexidade do comportamento animal e a serie de variaveis que ele envolve, sempre que posslvel deve-se evitar extrapolacoes com os resultados obtidos (HAFEz, 1970; KILGOUR, 1978; BANKS, 1982). 
Todo o comportamento animal e adaptativo, ou seja, o animal responde ao estimulo apropriado de diferentes formas. os animais comem, procuram abrigo, procriam e criam suas proles. Erros eventuais que venham a acontecer nestes comportamentos podem ser atribuldos ao fato de terem, os animais, sido colocados em situacoes pouco naturais (MANNING, 1972). Segundo HAFEZ (1969) comportamentos mal adaptados podem ser causados por auto motivacao, inabilidade para adaptar-se a situacoes novas e cativeiro. se os tres fatores estao presentes, 0 animal eventualmente mostrara alqum tipo de comportamento inapropriado, cuja natureza dependera do tipo de estimulo, da experiencia previa do animal e dos objetos e animais a sua volta.

Cada especie tem seu modo peculiar de comportamento; a selecao e a domesticacao nao produzem novos modelos, mas modificam os velhos. Entender o comportamento de uma especie em particular nao e somente conhecer as bases do modelo comportamental peculiar de cada especie e suas limitacoes, mas tambem conhecer os estimulos primarios, ou aquilo que os libera, e este entendimento e uma parte essencial para o sucesso da criaczo e manejo (HAFEZ, 1969; JOHNSGARD, 1973: FRASER, 1974).

A observacao dos animais faz-se necessaria para oue os estimulos sejam conhecidos, entendidos e estes conhecimentos aplicados. Sequndo observacoes de HAFEZ (1969, 1970), FRASER (1974), KILGOUR (1978) e o'sULLLIVAM (1985) os bovinos consomem seletivamente, escolhendo diferentes plantas na pastagem em diferentes estadios de maturacao. HAFEZ (1969) relatou que a seletividade e proporcional idade, pois animais mais velhos 
exibem-na mais acuradamente.

os bovinos nao pastam ininterruptamente no correr do dia, mas estabelecem perlodos de pastejo. Tém preferencia pelas primeiras horas da manha ou pelo final da tarde e em dias excessivamente quentes podem pastar d noite. vacas leiteira tem maior ingestao apos as ordenhas, sendo a maior delas observada no per1odo da manha (HAFEZ, 1969, 1970; FRASER, 1974). LUCCI et al11 (1972) encontraram trés picos de pastejo: o primeiro apos a ordenha da manha, o segundo apos a ordenha da tarde e um terceiro das 23:00 hs as 03:00 hs. POLLI \& LOBATO (1984) trabalhando com gado de corte encontraram cinco picos de pastejo, sendo 0 primeiro ao amanhecer e o Ultimo ao anoitecer.

Animais em grupo comem mais e ganham mais peso (HAFEz, 1970). CURTIS \& HOUPT (1983) relataram trabalhos com aves, onde se observou que uma galinha solitaria come uma determinada porca ate se satisfazer; porem, se uma segunda galinha faminta for introduzida na gaiola, a primeira, imediatamente, volta a comer. Esta caracteristica no entanto valida ate certo limite, pois com o aumento da lotacao pode haver decrescimo no ganho, nao compensado pelo numero extra de animais IGONYOU 8. STRICKLIN, 1981).

Para a determinacro do tamanho de uma baia coletiva em sistema de confinamento, o tamanho do cocho pode ser de fundamental importancia, uma vez que sera em funcao dele que se determinara a densidade animal. GONYOU \& STRICKLIN (1981) trabalharam com bovinos de corte jovens e adultos confinados: 
numa tentativa de reduzir o tamanho de baias coletivas. para tanto compararam dois sistemas de alimentacao, um com cocho tradicional e outro com alimentador individual automatico. Eles concluiram que embora o tempo de alimentaca decrescesse no sistema individual, a quantidade de alimento ingerido, bem como a performance dos animais foram semelhantes, indicando que os animais aprenderam a comer mais rapidamente no alimentador. segundo os autores, o resultado do experimento mostrou que alimentadores podem reduzir o tamanho das baias sem prejudicar o desempenho animal.

SHAW (1978) trabalhou com vacas leiteiras. usando um tipo de alimentador requlado por tempo, e observou que os animais tiveram um decrescimo de 218 na ingestao quando comparados com alimentacao "ad-libitum". No entanto, o ganho de peso nos dois tratamento foi iqual, o que levou o pesquisador a deduzir que os animas usando o alimentador tiveram melhor aproveitamento do alimento para crescimento e mantenca. EKELUND et a 1i 1 (1983) apontaram a dificuldade de se alimentar corretamente vacas confinadas, em virtude da grande variacao de producao leiteira que pode ocorrer dentro de um lote. LEITTLE \& HARRINSON (1984), trabalhando com vacas confinadas, observaram o numero de vezes em que os animais procuraram o alimentador individual e conclutram que somente $30,4 \%$ das visitas dava-se durante o dia. os autores notaram que determinadas vacas procuravam mais o alimentador do que outras, mesmo sabendo que nao encontrariam alimento.

Ruminaca e uma atividade restrita a certo numero de 
especies animais e compreende: regurgitacao, mastiqacao, reingestao e o intervalo entre a subida de bolos alimentares. os animais gastam nesta atividade, em media, trés quartos do tempo do pastejo, mas esta relacao influenciada pelo clima e pela quantidade e qualidade do alimento. Cada perlodo de ruminacao pode variar de dois minutos a uma hora ou mais. A ruminacao comeqa a aparecer antes que o bezerro cheque a 3 semanas de vida. Entretanto. os niveis de adulto ga geralmente alcancados quando - animal atinge 6 a 8 meses (HAFEZ, 1970). Sabe-se que em processos de aleitamento artificial e desaleitamento precoce do bezerro os niveis de ruminacao do adulto podem ser alcancados mas cedo (NOLLER, 1961). LUCCI (1989) relatou trabalhos realizados com bezerros holandeses desmamados aos 56 dias e submetidos a quatro dietas diferentes a saber: A sem alimentos volumosos; B, C e D com feno de alfafa, de capim de rhodes e silagem de milho, respectivamente, a partir da primeira semana de vida. Os dados encontrados mostram que os bezerros comecaram a ruminar na sequnda semana de vida. Nesta idade, animais com dietas sem volumosos ruminaram por cinco minutos, enquanto os animas submetidos a dietas com volumosos ruminaram por seis virqula dois minutos. Na setima semana de vida, os bezerros do tratamento a ruminaram por cento e oitenta e quatro minutos e os animas dos tratamentos B, C e D, ruminaram por trezentos e vinte e quatro minutos. Porem na decima semana foi observado uma reducao no tempo em que os animais passaram ruminando. os animais do tratamento a ruminaram por cento e cinquenta e sete minutos e os bezerros dos outros tres tratamentos ruminaram por duzentos e sessenta e seis minutos. Animais jovens sao normalmente mais 
timidos, e qualquer pertubacao externa produz uma interupcao na ruminacao. Muitas causas podem interromper ou paralisar a ruminacao: fome, dor, curiosidade, ansiedade, estresse, sons estranhos, pessoas desconhecidas e doenca (HAFEZ, 1969). LUCCI et ali (1969), trabalhando com gado gir confinado, observaram que embora animais alimentados com feno gastassem uma hora a menos para alimentar-se, o tempo de ruminacao foi iqual ao dos animais alimentados com silagem de milho e nao correspondeu aos tres quartos do tempo de ingestao descrito por HAFEZ (1969). POLLI \& LOBATO (1984), trabalhando com gado de corte em pastacem, observaram os tres quartos de tempo de pastejo descritos por HAFEZ (1970). MURESAN et alil (1985) observaram um tempo gasto em ruminasao de 10,9 a $11,8 \%$ do dia.

A ingestao de bqua e outro fator importante e depende, segundo HAFEz (1969), do sistema de criacao, da materia seca ingerida, idade do animal, temperatura ambiente, protelna e sal contidos na dieta, prenhez e lactacao. CowAN et a 111 (1978) em experimento com vacas leiteiras usaram dois sistemas de oferecimento de aqua: no primeiro os animais tinham acesso a aqua durante todo o dia, no sequndo este acesso era restrito a 20 minutos antes de cada ordenha. O resultado foi uma queda de $16 \%$ na ingesta de aqua do primeiro para o seoundo sistema mas a produca e a composicao do leite na foram afetadas. os autores encontraram ainda relacao direta entre a ingestao de doua $e$ a temperatura do ar. com isto demonstraram que o estudo do comportamento pode ajudar na reducá de gastos com instalacoes. mas advertem que estudos deste tipo devem ser repetidos, pois a 
extrapolacao dos dados pode nao conduzir a resultados semelhantes.

STOCKDALE \& KING (1983) relataram que o fator que mais influenciou o consumo de agua fol a chuva e so encontraram influencia da temperatura maxima quando removeram o efeito da chuva. os autores observaram que nas vacas que estavam sob pastejo ou sendo suplementadas com fero, a influencia da materia seca e da concentracao da materia seca sobre a ingestao de aqua foi, respectivamente, $2,30 \mathrm{~kg}$ por vaca por dia para cada kg de materia seca consumida e $0,053 \mathrm{ko}$ por vaca por dia para cada o/ko de aumento na concentracao de materia seca. Outros fatores que os autores encontraram relacionados com o consumo de aqua foram: temperatura minima, umidade relativa do ar, ventos, radiacao solar e evapotranspiracao.

A ordem social ou hierarquia de um arupo animal e outro fator importante dentro da etologia. BEILHARG \& ZEEB (1982) consideraram que os parametros da estrutura social variam de rebanho para rebanho e que a relacao de dominancia em um par de animas o resultado do aprendizado que vai desde os fatores triviais ate a formacao inicial do rebanho. A ordem de dominancia de um orupo nao pode ser mais do que a soma de relacionamentos individuas. Ainda sequndo os autores, os animais dominantes sao mais livres que os outros para atender a um estimulo vindo de fora do rebanho.

STEPHENS (1974) estudou o comportamento de bezerros de raca holandesa malhada de preto alimentados em aleitador 
automatico e criados em orupo. O autor observou que bezerros dominantes passavam mais tempo no aleitador e os dominados, por sua vez, ingeriam uma maior ouantidade de alimentos concentrados. Quando os bezerros foram desmamados, os dominados foram os que menos sentiram a mudanca.

o comportamento maternal nao somente a amamentacao do filhote. mas compreende todas as atividades desde o trabalho de parto ate a alimentaczo, passando pela limpeza do corpo e estimulacao sanqulnea (HAFEZ, 1970). O bezerro esta apto a mamar 1090 apos o nascimento, pois ele procura com a cabeca a teta na parte inferior do corpo da mae e se dirige para o ubere. Enquanto - bezerro mama, a vaca o lambe estimulando a eliminacao de urina e fezes. Os bezerros podem exibir preferencia por determinada teta, mas esgotada esta passam imediatamente para outra (FRASER, 1974). KILGOUR (1972) relatou que a habilidade materna e a producao de leite sao afetadas pelo sistema de criacao e alimentacao e que vacas leiteira criadas e alimentadas isoladamente nao abandonaram seus bezerros, alem de terem uma producao de leite mais reqular nos 305 dias de lactacao.

Estudos relativamente recentes deram enfase d pratica de deixar 0 bezerro com a mae nas primeiras 48 horas de vida como um modo de facilitar o maneio. Um experimento conduzido com 13 vacas que ficavam com os bezerros 12 a 48 horas apos o parto revelou que animais que parem e ficam com suas crias em baias isoladas sao mais cuidadosos com o bezerro. Por outro lado, as mantidas em baias coletivas tinham tendencia de abandonar os bezerros, ou a 
aceitarem bezerros de outras, desde que fossem mais novos que o seu (EDWARDS, 1983). CAMPOS (1984) relatou que o quanto antes os bezerros forem afastados da mae, majs cedo eles aprenderao a tomar leite no balde.

- comportamento e regido por gens, logo e hereditario (HAFEZ, 1969; MANNING, 1972; JOHNSGARD, 1973; FRASER, 1974; BANKS, 1982; e CURTIS e HOUPT, 1983). A capacidade de passar um determinado comportamento de uma geracao para outra MaNNING (1972) chamou de instinto. O autor enfatizou que o instinto pode ser modificado de acordo com o aprendizado. BANkS (1982) relatou que ate a data de publicacao do seu trabalho nao tinham sido efetuados estudos gue relacionassem o comportamento com a producao animal, embora acreditasse que a selecao artificial para produca pode, de alquma forma, determinar gens de comportamento.

STRICKLIN et alij (1980), trabalhando com gado de corte, observaram haver um fator de herdabilidade de temperamento da ordem de 0,4 a 0,48 . No entanto, a correlaca genetica entre temperamento e performance fol de baixa a moderada com desvio padra bastante alto. CURTIS \& HoUPT (1983) deram enfase ao fato de ser de grande importancia economica a selecao baseada no temperamento, uma vez que essa caracterlstica em muito facilita 0 manejo. BOGNER (1983), por outro lado, considerou impraticavel uma selecto de animais que alem dos caracteres relacionados a producao inclua tambem: comportamento social, sexual e capacidade de adaptacao.

A trangferencia do animal de um local com o qual esta 
acostumado para um outro completamente estranho pode gerar uma perturbacao emocional (HAFEz, 1969). A alta densidade pode gerar estado de estresse, tornando o animal agressivo (BANkS, 1982).

BANKS (1982) considerou que o manejo inadequado dos animais domesticos pode causar estresse com prejulzos d producao. e que os metodos para a determinacao deste estado atraves de andises fisiologicas com determinacres de componentes no soro podem alterar os resultados devido ao ato de retirar o sanque. - autor considera que a oeterminacao da variacao de comportamento atraves da observacao do animal serviria para dianosticar um estado de estresse sem aumenta-10. O ambiente pode sofrer modificacoes e assim atenuar situacoes que seriam desfavoraveis ao bom desenvolvimento dos animais (CURTIS 8 HOUPT. 1983).

KILGOUR (1978) relatou que atraves de observacao do comportamento seria possivel antecipar problemas, minimizar situacoes de estresse e com a sua continuidade permitir diagnosticar problemas subclinicos antes que estes se tornem evidentes. Situacoes estressantes podem levar o animal a exibir comportamentos inapropriados, que podera ser classificados, de acordo com HAFEZ (1969) e MANNING (1972). das sequintes formas:

a) a primeira edar a resposta certa, mas direciona-la no sentido errado - e caso da vaca que oolpeia a companheira quando golpeada pelo tratador,

b) a sequnda e responder de maneira errada - a galinha subitamente para de brigar e comeca a bicar em torno a st como se estivesse comendo. 
Estes comportamentos, ainda segundo HAFEZ (1969), podem ser causados por lesoes no sistema nervoso central, deficiencia enoocrina ou substancias toxicas.

FORDYCE et alii (1983) testaram tres racas de bovinos sob condicoes de estresse e demonstraram que as racas europeias sob condicoes adversas tém um temperamento mais docil do que as indianas.

os bovinos tem grande sensibildade auditiva. A maioria dos sons e ruldos, porem, the sao nocivos e estressantes. sao mais senstveis aos sons de alta frequencia que os humanos. Sons de trovoada aumentam de 50 para 70 batidas por minutos no coracao de bezerros; sons aqudos e barulhentos sao neqativos, enquanto os sons suaves sao favoraveis. O bovino reage neoativamente aos gritos e berros do homem. Vazamento de ar provoca forte reacao contraria, e ruldos provocados por friccao de ferro sao irritantes (MACHADO, 1980).

ROOIJEN (1983) deu enfase ao fato de que falando em estresse pensa-se em proporcionar conforto para os animais, mas que nao se deve esperar que o estresse e o conforto sejam avaliados de acordo com as caracteristicas e necessidades dos seres humanos. Deve-se evitar antropomorfismo e pensar no animal como animal.

SCHMISSEUR et ali (1966) compararam dois tipos de confinamento e observaram que as vacas no sistema de area de repouso em conjunto agiam mais em orupo, pois varias vacas 
levantavam e iam comer simultaneamente e que as vacas dominantes comiam primeiro. No sistema de "free-stall", os animais sao mais individualistas e a acao em grupo menos evidente. Ainda neste sistema, as vacas descansavam 2:00 h a menos do que no de area de repouso em conjunto. Quando as vacas tiveram livre acesso a ambos os sistemas, houve a manifestasao clara da preferencia dos animais pelo sistema de area de repouso em conjunto. Somente $50 \%$ das vacas do "free-stall" permaneceram nas instalacoes e, sequndo os autores, isto esta de acordo com trabalhos experimentais, onde foi observado que vacas podem ser treinadas ou forcadas a usar o "free-stall", mas a preferencia seria por locais de descanso maiores.

Diferentes animais tém diferentes necessidades para um crescimento otimo, e isto depende da habilidade que estes animais tem para se adaptarem a condicoes do ambiente. os parametros comportamentais podem propiciar uma indicacao precoce do potencial da condicao desadaptativa, o que pode afetar o bem estar animal e a produtividade (UERGA et alii, 1895). Esta afirmacao foi ilustrada com um experimento em que foram testados dois tipos de piso: um constituldo de ripado de madeira e outro de borracha, em baias de criacao de vitela. o consumo de leite foi absolutamente o mesmo nos dois tratamentos, mas os animais que ficaram em balas com piso emborrachado passaram mais tempo de pe e tiveram maior alteracao nas atividades de lamber objetos ou seu proprio corpo do que os animais do outro grupo. Os animais do grupo que passou mais tempo em pe tiveram menor ganho de peso. - que levou os pesquisadores a concluirem que a avaliacao do 
comportamento pode ser uma forma de diagnostico precoce de estresse, uma vez que as diferencas no desenvolvimento animal so poderao ser dignosticadas mais tarde, quando mutas vezes e tarde demais para se tomar alquma providencia.

Muitas das caracteristicas demonstradas na idade adulta dos animais sao resultados de experiencias na idade jovem. Este fato foi muito bem demonstrado em estudos com macacos Rhesus $e$ galinhas domesticas. Estes animais quando criados isoladamente exibiam serios desvios comportamentais. Com bovinos os desvios encontrados nao foram menores, observando-se alteracoes na habilidade materna, baixo desempenho sexual, percepcao sensorial anormal, comportamento agressivo com os animais da mesma especie e com o homem. Desvios estes apontados como resultado da forma de criacao (BROOM \& LEAVER, 1978; ARAVE et alii, 1985). DELLMEIER et ali1 (1985) trabalharam com bezerros confinados desde o nascimento e sugeriram que a criacao dos animais em baias menores acarretou uma supressa cronica de movimentacao que foi acompanhada por resposta fisiologica associada com estresse cronico.

- ato de lamber entre os bezerros a a de ocorrencia corriqueira. De acordo com citacoes de SATo (1984), a acao de lamber ou nao lamber e uma caracteristica individual do animal, ja a acao de receber lambidas parece ser generalizada. O mesmo autor acreditou que o ato social de lamber entre os bezerros pudesse estar relacionado com o ganho de peso. Para comprovar sua teoria, observou quarenta e seis bezerros de corte desmamados - 
vinte e tres femeas e vinte e trés machos - agrupados por sexo, em duas baias. o autor somente considerou o lamber social, ou seja, fol excluido o ato de lamber vulva, penis e ubere. A conclusao a que cheqou o autor foi de que o ato de ser lambido est positivamente relacionado com o ganho de peso. Desta forma, a lambida ou limpeza social teria por funcao nao so a limpeza do pelo, mas tambem promover uma estabilidade psicologica nos animais. O autor citou ainda um trabalho de wood (1977) que demonstrou estar tambem a producao de leite positivamente relacionada com o tempo em que o animal passa sendo lambido.

WEBSTER et ali (1985) estudaram o comportamento de bezerros confinados nas diversas condicoes de exploracao comercial, procurando determinar quais as condicoes que poderiam ser consideradas condenaveis em termos de bem-estar animal. Foram estudados cinco sistemas de criacao, sendo tres para obtencao de reprodutores, a saber: a pasto, em baias individuais e em baias coletivas e dois para criaca de vitelos: em baias individuais ou em qrupo. A conclusao a que chearam os autores foi a sequinte: bem-estar e uma avaliacao subjetiva. Todos os animais se desenvolveram bem, sem que houvesse diferencas sionificativas entre os sistemas estudados. Apenas um sistema poderia ser contra indicado: a criaca de vitelos individualmente, devido a restricto de movimentos que impre ao animal. WARNICK et ali (1977), por outro lado, comentaram que o sistema de criacao tem uma grande influencia sobre 0 ganho de peso dos animais e sobre o comportamento social. No trabalho conduzido pelos autores, os bezerros criados isoladamente, ou geja, sem contato visual com os 
em bajas individuais. mas com contato visual com os companheiros. os animais isolados necessitaram de mais medicamentos do que os criados individualmente ou em grupo. Apos o desmame. quando os animals foram agupados, aqueles criados isoladamente se colocaram no final da hierarquia social. Este fato foi tambem demonetrado por BROOM \& LEAVER (1978). Bezerros criados em orupo, ainda de acordo com WARNICK et alii (1977), iniciaram o consumo de feno e concentrado mas cedo do que os criados em outros sistemas e, como aprenderam a competir antes pelo alimento, foram os que se desenvolveram melhor apos o desmame.

KERR 8. WOOD-GUSH (1987), tambem trabalhando com bezerros, concluiram que aparentemente o temperamento dos animais e determinado na idade jovem. De acordo com os autores, a partir da vigesima semana de vida nao ha mais alteracoes no temperamento dos animais. Como forma de mensurar o temperamento os autores utilizaram-se da reacao dos animais frente ao toque do homem. As reacoes variaram desde evitar o toque, afastando-se. ate responder ao toque, com o movimentar do focinho.

Donaldson (1967 e 1972), citado por ARAVE et alii (1985), relatou trabalhos experimentais onde bezerras criadas individuamente tornaram-se vacas menos dominantes e melhores más do que bezerras criadas em arupo de trés. procurando comprovar esta observacao. ARAUE et ali i (1985) trabalharam com quatro tipos de sistemas de criacao: grupo de seis animais, animais em baias individuais, animais em baias isoladas (em que nao podiam ver ou ouvir seus companheiros, nem tinham contato 
visual com o homem), animais isolados, mas com contato visual somente com o homem. Durante toda a fase de desenvolvimento nao houve diferenca sionificativa no peso dos animais. Quando atingiram a idade adulta, as novilhas que haviam sido criadas em grupo eram mais atentas para receber alimento nos alimentadores eletronicos do que as demais. Quanto a producao de leite, os animais que haviam sido criados em isolamento produziram sionificativamente mais leite do que os animais criados nos outros sistemas. A raza encontrada pelos autores para este fato foi que bezerras criados isoladamente tornam-se mais doceis, menos agressivos e entram na rotina de producao de leite, na socializacao com o homem mais facilmente do que os animais criados em contato com outros animais. Contudo, ressalvam que esta diferenca na producăo exigiria maiores estudos. 


\section{MATEEIAL E METODOB}

- experimento fol realizado na Escola superior de Agricultura "Lulz de oueiroz", no Departamento de zootecnia, secao Ruminantes e constou de duas fases a saber: fase pre experimental e a fase experimental propriamente dita.

\subsection{Fate Pro=Experiment}

Iniciou-se no dia 02/02/87, teve duracao de 32 dias. ou seja, ate o dia $05 / 03 / 87$.

A finalidade desta fase foi testar as planilhas para anotacoes das atitudes comportamentais, aferir os criterios de anotacoes entre os observadores e adequar o manejo dos animais. Para tanto utilizou-se de 9 (nove) animais da raca holandesa preta e branca com idades variando de 0 (zero) a 8 (oito) dias. os animais eram originarios do rebanho do Departamento de Zootecnia e de uma fazenda da regia.

\subsection{Fage Experimental}

3.2.I Tempo de Realizacto do Experimento

o experimento iniciou-se no dia $06 / 03 / 87$, quando os animais foram pesados e distribuidos nas baias.

Para que os animais tivessem tempo de se habituarem as novas condicces de criacao, a primeira observacao so foi realizada no dia 14/03/87. As demais observacoes deram-se nos 
dias 20/03; 27/03; 04/04; 11/04; 17/04;24/04;01/05;09/05e $15 / 05$.

- experimento encerrou-se no dia $16 / 05$ com a ultima pesaọem dos animais.

\subsection{Medictes}

Foram coletados dados de consumo de racao concentrada, peso dos animais, temperatura ambiente, umidade relativa do ar e precipitaca pluviometrica. os dados de precipitacao e umidade relativa foram obtidos junto ao posto meteorolopico do Campus, que dista $200 \mathrm{~m}$ do local do experimento. os dados de temperatura ambiente foram obtidos com um psicrometro instalado dentro do estabulo.

\section{2.3 Tratamentos}

- experimento constou de dois tratamentos com seis repeticoes cada. No tratamento I os animais eram mantidos em

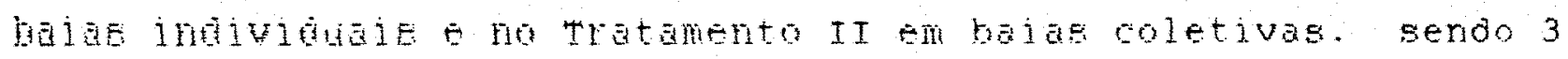
animais em cada uma das duas baias.

Dentro de cada tratamento os animas foram numerados de 1 a 6 .

\subsubsection{Animais}

Foram utilizados 3 (trés) animas machos da raca Holandesa preta e branca, orioinarios do rebanho do Departamento de zootecnia, e 9 (nove) oriainarios da fazenda pinhalzinho, situada no municipio de Araras, a mesma que havia cedido os 
animais para a fase pre-experimental.

optou-se pela utilizacao de machos por serem estes animais de menor valor comercial em racas leiteiras.

os animais for am sorteados dentro dos tratamentos e nas balas que foram dispostas como indicado na fIGURA 01.
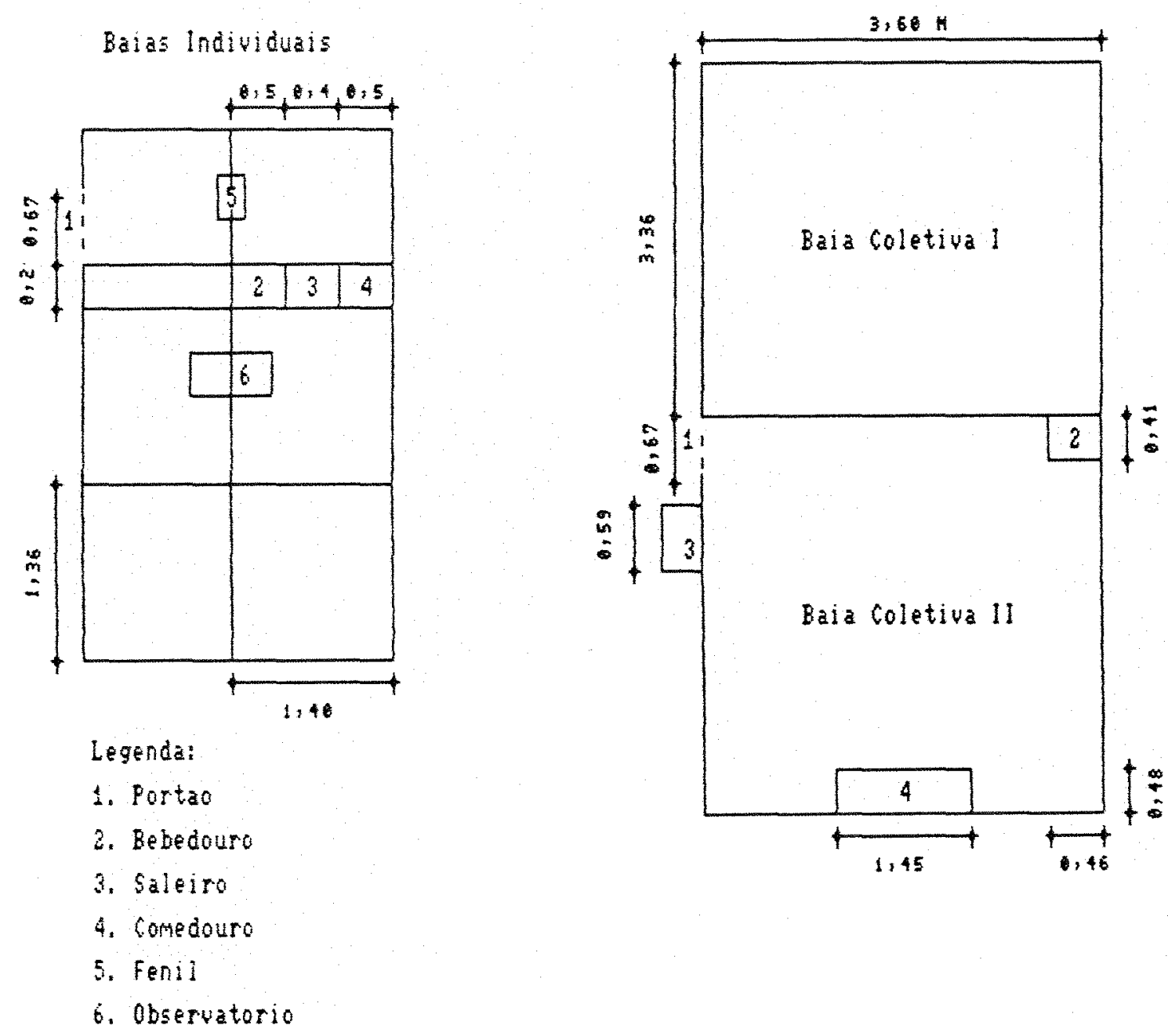

FIGURA 01. Esquema das baias usadas no trabalho experimental. 
Na. TABEla 01 pode-se observar a idade e o peso inicial dos animais nos dois tratamentos estudados.

TABELA 01 - Idade e peso dos animals no inicio do periodo experimental, dia $06 / 03 / 87$.

\begin{tabular}{|c|c|c|c|}
\hline TRATAMENTO & ANIMAIS & $\begin{array}{l}\text { IDADE } \\
\text { (di모) }\end{array}$ & $\begin{array}{l}\text { PESO } \\
\text { (Kg) }\end{array}$ \\
\hline \multirow{6}{*}{$I$} & 1 & 17 & 50.0 \\
\hline & 2 & 11 & 31,6 \\
\hline & 3 & 11 & 46.4 \\
\hline & 4 & 10 & 43,1 \\
\hline & 5 & 8 & 47.0 \\
\hline & 6 & 4 & 28,6 \\
\hline \multirow{6}{*}{ II } & 1 & 8 & 39,0 \\
\hline & 2 & 6 & 43.8 \\
\hline & 3 & 4 & 44,6 \\
\hline & 4 & 6 & 28,1 \\
\hline & 5 & 9 & 34.8 \\
\hline & 6 & 5 & 31,4 \\
\hline
\end{tabular}

Tratamento I - Baia Individual; Tratamento II - Baia coletiva

\subsubsection{Manejo dos Animais}

os animais foram pesados no dia em que foram dispostos nos dois tratamentos e a cada semana, apos jejum alimentar de 12 horas.

A alimentacto constou de: racao granulada Anhaquera inicial para bezerros, cuja quantidade de materia seca (Ms) era de $90 \%$, com consumo a vontade ate $2,5 \mathrm{~kg} / \mathrm{cab}$ dia, feno de capim de rhodes "ad libitum" e leite de vaca integral, 4 1/cab.dia, dividido em 2 vezes. Fol ainda fornecido sal e doua d vontade.

Apenas o consumo de racao foi menaurado diariamente, atraves da pesagem das sobras, apos o que erafornecido racao nova. 
como criterio para os desmame foj utilizado a apreciacao do aspecto geral dos animais e um consumo de racao iqual ou superior a 800 ge racao oranuiada por dia.

A I impeza das baias foi realizada diariamente. sempre no mesmo horario. quando os animas eram soltos no patio, onde permaneciam durante 1 hora.

Como a observacao noturna dos animais requeria claridade, as luzes do estabulo permaneciam acesas durante todas as noite, mesmo quando os animais nao estavam em observacao. para que nao houvesse nenhuma alteracao nos dias de observacao.

\section{2 .6 observacoes}

As coletas de dados foram feitas semanalmente cada observacao teve duracao de 24 horas dividida em tres subperiodos de 8 horas cada, para que se fizesse a alternancia de observadores. As atividades desenvolvidas pelos animais foram anotadas a cada tres minutos em planilha incluida no apendice.

o observador situava-se em local estrategico, a $3.0 \mathrm{~m}$ de altura, para que pudesse visualizar todos os animais em experimentacá com o minimo posslvel de interferencia. o local do observatorio est anotado no croqui.

As atividades dos animais observadas, com anotacao do tempo de duracao foram:

E* - permanencia em pe desenvolvendo qualquer atividade. 
Deseano - permanencia em pe sem desenvolver nenhuma atividade.

Bebendo ou - permanencia no bebedouro com o focinho dentro d'agua.

Comende velumero - de pe, mastiando o feno na manjedoura.

Rumiano e requroitando e remastioando o alimento, em pe.

comende eonentrado - junto ao cocho de racao mastiqando os "pelets".

Lambende - passando a Ilnqua em qualquer parte do seu corpo, em pe.

Lambendo o companheito - passando a linoua pelo corpo do companheiro, sendo que o animal ativo estava em pe.

Lambendo - passando a Iingua no sal do cocho.

Lambende objeton - passando a Inoua em tudo que nao fosse ele mesmo, o companheiro ou sal. tanto dentro da baia como no patio.

Cofande= - passando a pata traseira em qualquer parte de seu corpo.

Bueando o companhe ro - succionando qualouer parte do corpo de outro animal.

sueande a la - succionando as partes da baja posslveis de envolver com a boca.

obaervando - olhando para o exterior com a cabesa do lado de fora da baia.

Andando - andando pela baia ou patio, incluindo a procura de um bom luar para se deitar. 
Correndo - o animal correndo dentro da baia ou no patio.

Brigande - dando cabecada no companheiro.

Deitado - desenvolvendo qualquer atividade. desce que deitado.

Em defano deitado - deitado sem desenvolver qualquer outra atividade.

Dot na - deitado com a cabeca encostada no corpo, ou deitado sobre um dos flancos com as pernas estiradas, em ambos os casos com os olhos fechados.

Cemeno velumero deitado - ingerindo e mastigando feno caldo da manjedoura.

Ruminade detade - requroitando e remastioando, deitado.

Lambendo = dido - passando a ingua sobre o seu corpo.

\section{Lambendo deltado - lambendo alqo que nao a sl mesmo.}

Para as atividades descritas foi contabilizado o tempo, em minutos, durante o qual o animal as executou e o numero de vezes que foram executadas. Contou-se ainda o numero de vezes em que os animais urinaram, defecaram ou colocaram as patas dianteiras sobre outro animal. simulando a cobertura.

3.2.7 Andise dos dados

Para a analise dos dados foi elaboraco um proarama de computador na linouagem "Turbo Basic" que efetuou a somatoria dos tempos oastos em cada atividade estudada e contabilizou o 
numero de vezes em que cada atividade foi efetuada pelos animais individualmente.

o tempo total que os animais permaneceram em pe e o tempo total deitado foram comparados entre os tratamentos atraves do teste $F$, pois fol adotado o delineamento experimental inteiramente casualizado. Os dados de peso ao desmame e idade no desmame foram comparados, tambem, atraves do teste $F$.

As observacres dentro do tempo em pe e tempo deitado foram analisadas graficamente, pois, para que a andise estatistica possa ser aplicada, enecessario que os dadog experimentais obedecam a certos pre requisitos. De acordo com Lord Rutheford, citado por MARTIN \& BATERSON (1986), "Se o seu experimento precisa de estatistica vocé deve fazer um experimento melhor." E o que se ve acontecer em trabalhos experimentais e que a andise estatistica esta cada vez mais sendo usada sem que se observe a adequaca ou nao do modelo utilizado. Em experimentos sobre comportamento este fato ainda mais evidente, como afirmam HOESKSTRA \& JANSEN (1986), que nos anos de 1984 e 1985 encontraram vinte e cinco experimentos publicadas no periodico "Applied Animal Behavior science", onde os metodos estatisticos estavam sendo usados de maneira incorreta. O erro principal eque os autores dos trabalhos se esquecem de considerar que em estudos de comportamento os dados coletados nao sa independentes entre si.

os modelos estatisticos convencionais partem do pressuposto que os dados tenham uma distribuicao independente, o 
que nao ocorre com padroes comportamentais. Dessa forma, estes modelos devem ser evitados (ANDERSON, 1974; HOESKTRA \& IANSEN. 1986).

o que pode ser usado para a avaliacao dos resultados de experimentos comportamentais e a andise exploratoria dos dados, ou seja a andise descritiva, que tem por objetivo aprender com os dados obtidos, funciona quando a hipotese e vaga e tem como importantes recursos o uso de graficos ou histogramas (MARTIN \& BATERSON, 1986). 


\section{REBULTADOB E DIBCUBBAO}

\subsection{Temperatura e Umidade}

A TABELA 02 nos mostra os dados meteorologicos dos dias de observacao e dos dias imediatamente anteriores.

Como pode ser verificado, nao houve variactes orasticas nas condicoes climaticas durante os tres meses de observacao, a nao ser no dia $04 / 04$ quando ocorreu precipitacao, e em funcao disto uma maior umidade relativa e temperaturas mais baixas. Portanto, provavelmente o clima nao tenha se constituldo em um fator relevante na alteraca do comportamento dos animais. Desta forma, ofator clima nao fol considerado na analise dos padros comportamentais.

TABELA 02 - Dados meteorologicos dos dias em que foram feitas as observacoes e do dia imediatamente anterior.

\begin{tabular}{|c|c|c|c|c|c|c|}
\hline \multirow[b]{2}{*}{ DIA } & \multirow[b]{2}{*}{ MES } & \multirow[b]{2}{*}{ PPT $(\mathrm{mm})$} & \multirow[b]{2}{*}{ UR: } & \multicolumn{3}{|c|}{ TEMPEBATUBA } \\
\hline & & & & MAX & MIN & MEDIA \\
\hline 13 & 03 & 0,0 & 65,8 & 28,6 & 12,2 & 20,4 \\
\hline 14 & 03 & 0,0 & 69,4 & 31,9 & 15,0 & 23,4 \\
\hline 19 & 03 & 0,0 & 74,6 & 29,9 & 16,9 & 23,4 \\
\hline 20 & 03 & 0.0 & 67,7 & 30,9 & 16,9 & 23,9 \\
\hline 26 & 03 & 0,4 & 73.7 & 33,2 & 18,9 & 26,0 \\
\hline 27 & 03 & 0,5 & 78,2 & 33,9 & 19,9 & 26.9 \\
\hline 03 & 04 & 9,2 & 82,8 & 25,3 & 19,4 & 22,3 \\
\hline 04 & 04 & 17,7 & 90,8 & 19,7 & 16.9 & 18,3 \\
\hline 10 & 04 & 6,6 & 79,6 & 31,8 & 19,0 & 25,4 \\
\hline 11 & 04 & 0,0 & 76,3 & 30,9 & 18,8 & 24,8 \\
\hline 16 & 04 & 0,0 & 65,5 & 32,7 & 19.8 & 26,2 \\
\hline 17 & 04 & 0,0 & 67.1 & 33,1 & 18,5 & 25,8 \\
\hline 23 & 04 & 0,0 & 74,4 & 30,2 & 18,6 & 24,4 \\
\hline 24 & 04 & 0,0 & 71,9 & 28,8 & 17.0 & 22,9 \\
\hline 30 & 04 & 0,0 & 75,5 & 27,7 & 17.2 & 22,4 \\
\hline 01 & 05 & 0,0 & 75,4 & 28,5 & 14,6 & 21,5 \\
\hline 08 & 05 & 8,2 & 85,4 & 29,8 & 21,2 & 25,5 \\
\hline 09 & 05 & 0,0 & 77,2 & 24,8 & 16,0 & 20,4 \\
\hline 14 & 05 & 0,0 & 65,5 & 28,6 & 17,4 & 23,0 \\
\hline 15 & 05 & 30.4 & $-82+9$ & 27.8 & 19,4 & 23.6 \\
\hline
\end{tabular}

Fonte: Posto agrometeorologico da ESALQ. 


\section{2 - Desmame}

Os animais, ao iniciarem o experimento, tinham idades diversas e, desta forma, o desmame de todos os animais nao foi realizado numa mesma epoca. Os criterios usados para que se efetuasse o desmame fol o aspecto geral dos animais e o consumo de racao concentrada. A TABELA 03 mostra, depoca do desmame, o peso, a idade e o consumo de racá concentrada.

TABELA 03 - Idade, peso e consumo de racao concentrada por ocasido do desmame.

\begin{tabular}{|c|c|c|c|c|}
\hline TRATAMENTO & ANIMAIS & $\begin{array}{l}\text { IDADE } \\
\text { (dias) }\end{array}$ & $\begin{array}{l}\text { PESO } \\
\text { (Kg) }\end{array}$ & $\begin{array}{l}\text { CONSUMO } \\
(g / \text { dia })\end{array}$ \\
\hline$I$ & $\begin{array}{c}1 \\
2 \\
3 \\
4 \\
5 \\
6 \\
\text { media }\end{array}$ & $\begin{array}{l}37 \\
43 \\
51 \\
41 \\
39 \\
60 \\
45,7\end{array}$ & $\begin{array}{l}64,0 \\
53,0 \\
69,0 \\
53,0 \\
55,0 \\
56,4 \\
58,4\end{array}$ & $\begin{array}{r}1500 \\
1000 \\
960 \\
1500 \\
1200 \\
1400 \\
1260\end{array}$ \\
\hline II & $\begin{array}{r}1 \\
2 \\
3 \\
4 \\
5 \\
6 \\
\text { media }\end{array}$ & $\begin{array}{l}48 \\
47 \\
44 \\
62 \\
62 \\
61 \\
54\end{array}$ & $\begin{array}{l}59,0 \\
58,0 \\
60,0 \\
50,0 \\
53,4 \\
55,4 \\
67,6\end{array}$ & $\begin{array}{c}1073+ \\
1073+ \\
1073+ \\
1448+ \\
463+ \\
1448+ \\
1096,3\end{array}$ \\
\hline
\end{tabular}

Tratamento I - Baias Individuais; Tratamento II - Baias Coletivas

+ Consumo medio na baia

* Consumo medio na baia quando o bezerro passou a refugar o leite.

Como pode ser observado na TABELA 03, a maioria dos animais por ocasiao do desmame ja consumia quantidades de concentrado superiores a 800 diarias, o que, de acordo com CAMPOS (1984), e considerado quantidade sufjciente para se 
proceder ao desmame. GOMES (1983) relatou que bezerros desmamados quando consumiam $400 \mathrm{~g}$ diarias de racao concentrada tiveram desempenho iqual dqueles que consumiam 800o. APPLEMAN \& OWEN (1975) citaram diversos trabalhos onde 0 consumo de racao concentrada considerado ideal para se proceder ao desmame estaria entre 454 e 907 g/dia, mas comentaram tambem que o fato de nao fornecer leite todos os dias aos animais estimula o consumo de alimentos solidos.

A idade media do desmame foi inferior citada por ARAVE et alil (1985), que desmamaram os animais com idade variando de 52 a 75 dias, mas superior a quatro semanas que, segundo CAMPOS (1984), e a idade a partir da qual e possivel fazer o desaleitamento precoce. De acordo com revisao elaborada em 1975 por APPLEMAM \& OWEN, o desmame pode ser entre a terceira e a quinta semana de vida, e os criterios podem ser: idade, ganho de peso e ingestao de concentrado. Segundo esta mesma revisao, a partir da decima segunda semana de idade ha um ajuste no desenvolvimento dos animais; os bezerros desmamados precocemente tem maior consumo de concentrado, compensando assim a perda eventual de peso devido ao desmame precoce.

Na TABELA 04 pode ser vista a andise de variancia para a idade e o peso vivo na epoca do desmame. Como pode ser observado, nao houve diferenca sionificativa para estes dois parametros entre os dois tipos de baias, o que indica nao haver influencia dos tratamentos sobre a idade do desmame e sobre o peso dos animais por ocasizo do desmame. 
TABELA 04 - Analise de variancia para a idade e peso vivo por ocasiao do desmame.

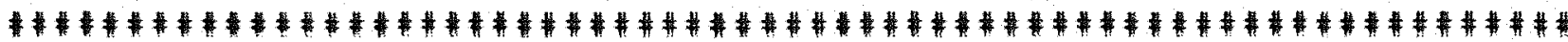

Andise de Variancia para Idade

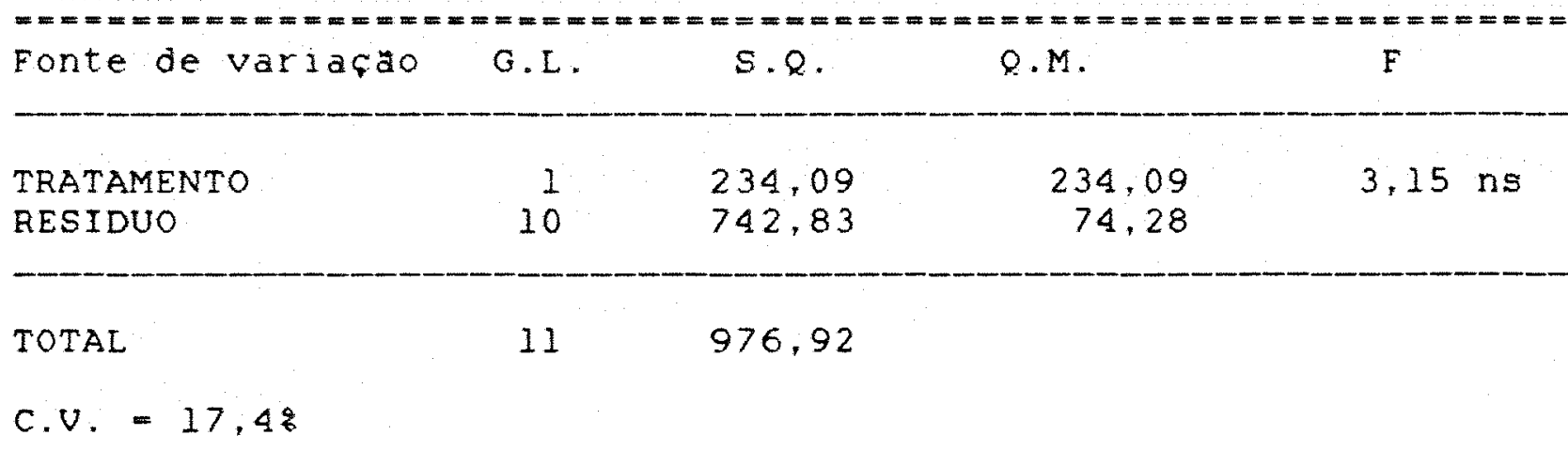

Analise de Variancia para Peso vivo

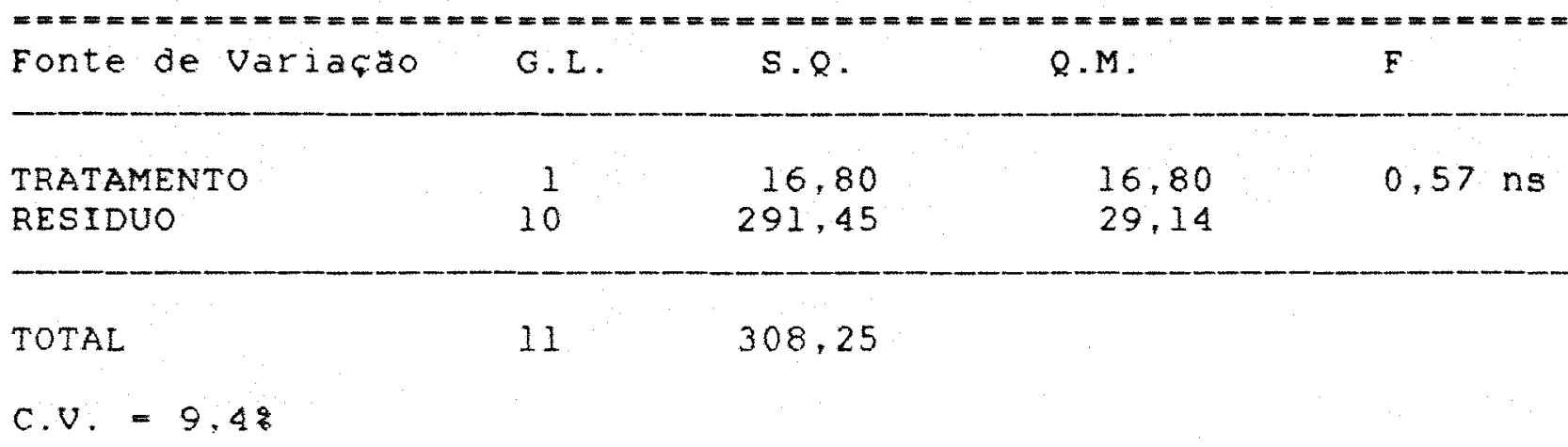




\section{3 - Desenvolvimento}

\subsubsection{Ganho de Peso}

Os animais, ao iniciarem o experimento tinham idades diversas. Para eliminar este fator sobre o ganho de peso, os dados foram considerados a partir da idade de 17 dias, ou terceira semana, que era a idade do animal mais velho no inicio do experimento. o peso final considerado foi o do animal mais novo ao termino do experimento, com 76 dias ou decima primeira semanas.

Na TABELA 05 observa- se o peso dos animais aos 17 dias e aos 76 dias, o consumo total de racao concentrada e o ganho de peso no periodo. As medias de ganho de peso durante o periodo experimental foram de $38,3 \mathrm{Kg}$ para as baias individuais e de 35,7 Kg para as baias coletivas. Os bezerros do tratamento I foram mais pesados desde o inlcio do perlodo experimental e, de acordo com ROY ( $1970 a)$, o peso ao nascimento influencia sobre o peso e o requerimento de nutrientes do animal ate a idade de 6 meses com alimentacao "ad-libitum", enquanto o peso ao nascer e influenciado pelo nivel nutricional da ma e pelo tempo de gestacao. Para bezerros holandeses malhados de preto esperado um ganho de peso de $0.6 \mathrm{~kg} / \mathrm{dia}$ nos primeiros tres meses de vida (ROY, 1970a; LUCCI, 1989). No presente experimento os ganhos de peso diarios obtidos no periodo de 59 dias foram de $0.65 \mathrm{Ko} e$ 0,60 Ko para as baias individuais e coletivas, respectivamente. LUCCI (1989) citou trabalhos realizados com bezerros holandeses machos desaleitados aos 50 dias de idade, com racao iniciadora "ad-libitun" e feno tambem "ad-libitum" em que foram obtidos 
ganhos de peso acumulados, dos 15 aos 78 dias de idade, de $32,0 \mathrm{~kg}$. Portanto, os ganhos de peso obtidos em ambos os tratamentos podem ser considerados normais para a jade e raca utilizadas.

TABELA 05 - Peso dos Animais ( $\mathrm{Kg}$ ) aos 17 dias e aos 76 dias, consumo total de racao concentrada (Kg) e ganho de peso ( $\mathrm{Kg}$ ) no pertodo.

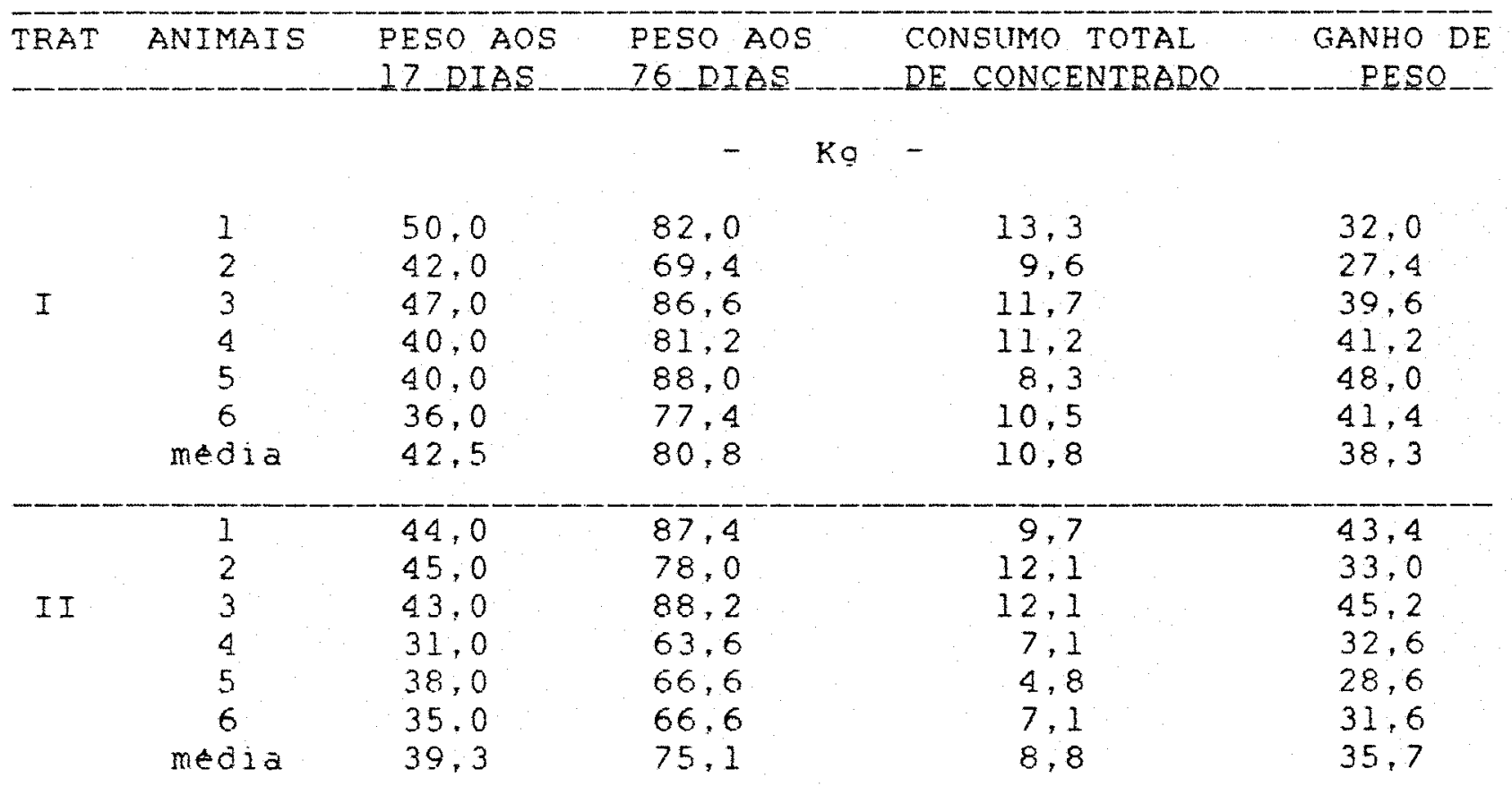

Tratamento I - Baias Individuas; Tratamento II - Baias coletivas

A FIGURA 02 ilustra em forma de curva o desenvolvimento dos animais, nos dois tratamentos, a partir da terceira semana de idade ate ofinal do experimento. A analise visual do grafico indica que o ritmo de crescimento foi aparentemente o mesmo para os dois sistemas estudados, uma vez que as curvas foram relativamente paralelas. Assim sendo, pode-se inferir que o tipo de baia na tenha exercido influencia decisiva sobre o crescimento dos bezerros. BROOM \& LEAVER (1978), trabalhando com 
bezerros leiteiros criados isoladamente e em orupo durante oito meses, nao encontraram diferenca sionificativa no peso dos animais quando compararam esses dois sistemas de criacao. O mesmo resultado foi encontrado por FRIEND et alli (1985). Por outro lado, WARNICK et alli (1977) verificaram que animais em grupo apresentaram um maior ganho de peso no pos desmame do que animais criados isoladamente.

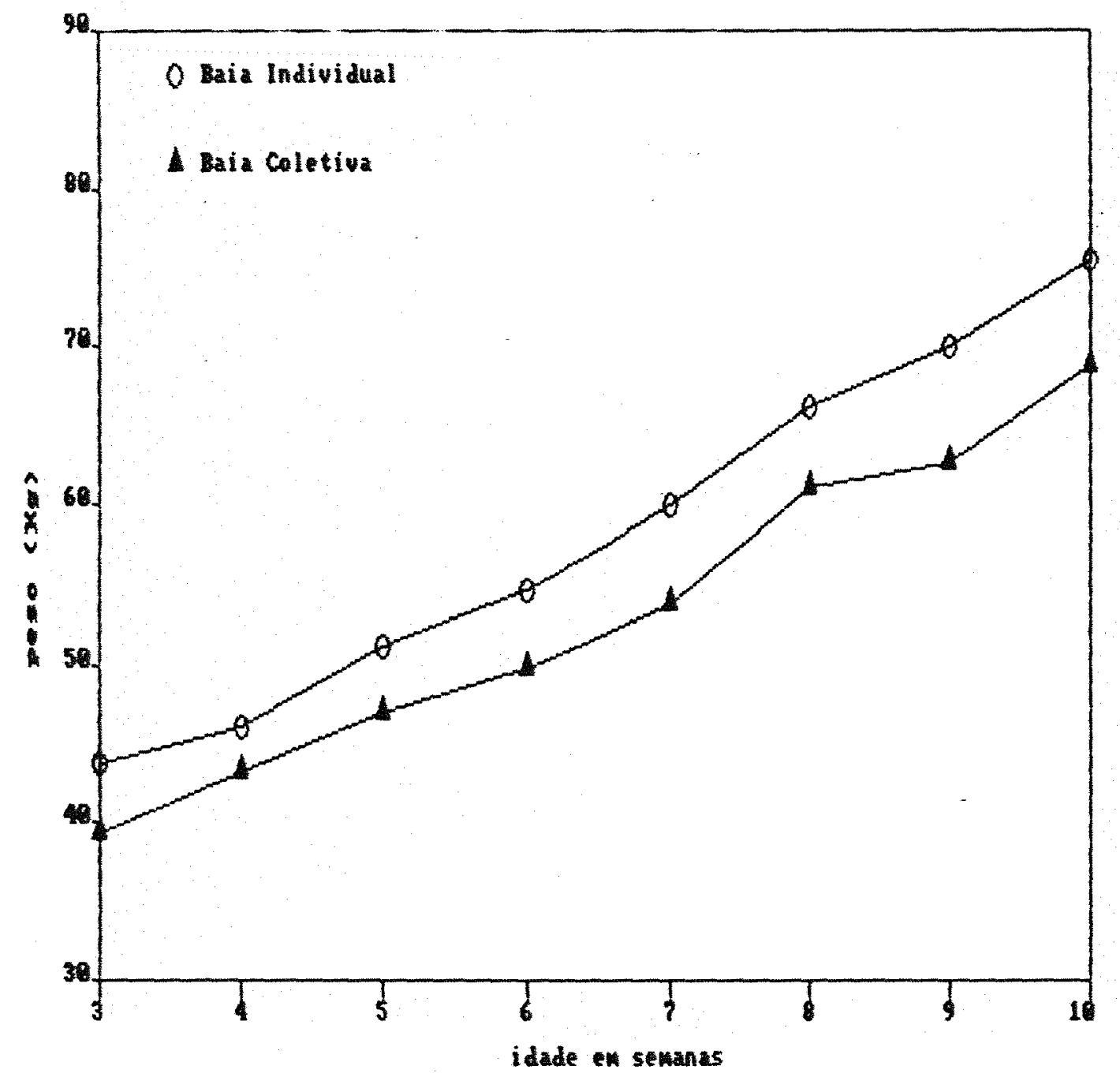

$\begin{aligned} \text { FIGURA } 02 \text { - } & \text { Desenvolvimento dos animais, nos dois tratamentos, a } \\ & \text { partir da terceira semana ate a decima. }\end{aligned}$ A media disria de consumo de concentrado pode ser observada na FIGURA 03, onde as tendencias nao ficaram bem 
definidas. Da terceira ate duinta a semana de vida o consumo pode ser considerado iqual nos dois tipos de baias. Ja a partir da quinta semana houve um maior consumo de racáo concentrada nas baias individuais, o que discorda das observacoes de HAFEZ (1970) e GONYOU \& STRICKLIN (1981), segundo os quais o consumo pode ser estimulado pela concorrencia entre os animais. Entretanto, poderia ser considerado que o maior peso dos animais nas baias individuais foi ofator determinante do maior consumo aparente. De acordo com o NRC (1989) o consumo de animas em crescimento e o respectivo ganho diario de peso sao funcoes do peso vivo.

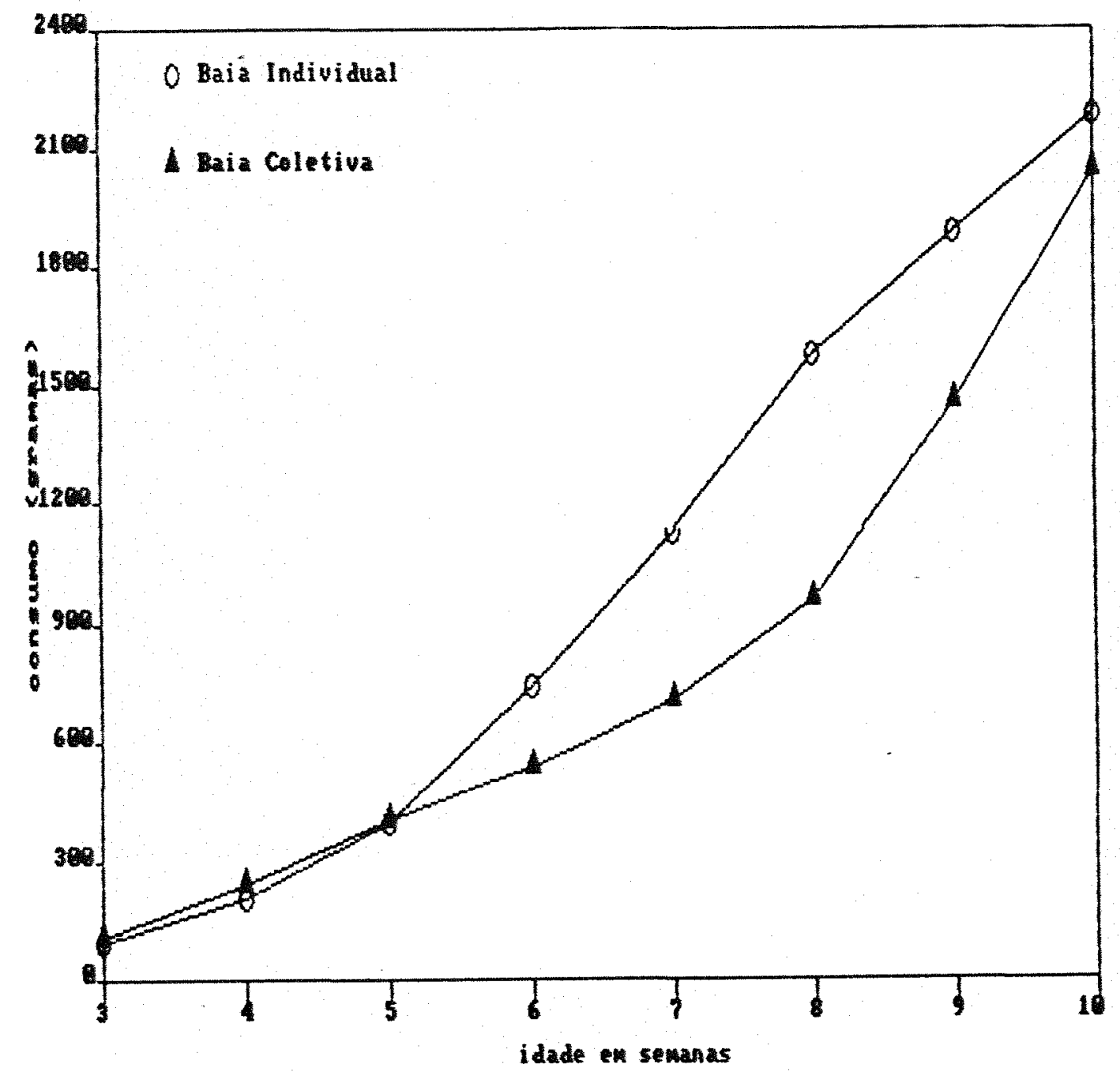

FIGURA 03 - Consumo de racao concentrada. 
Pode-se notar, em ambas as curvas, dois pontos de inflexao. Na curva correspondente ds baias individuais, este ocorre entre a quinta e a sexta semana de idade e na curva das baias coletivas ocorre por volta da oltava semana de idade. Essas idades correspondem ao desmame da maioria dos animais nos referidos tratamentos, o que explicaria maior procura de alimento concentrado. A partir de entao, verifica-se tendencia a um consumo crescente o que seria esperado, uma vez que nao ha mais o fornecimento de leite. A curva referente as baias individuais apresenta outra inflexa na oitava semana, indicanoo gue o aumento no consumo ocorrido nas baias individuais foi menor do que nas baias coletivas, isto pode ser explicado pelo adoecimento de dois animais nas baias individuais que apresentaram reducao no consumo.

\subsection{2 ocorrencia de doencas}

De acordo com WARNICK et alii (1977) os dados relativos a ocorrencia de doenca, em experimentos com bezerros, sao diflceis de serem avaliados, por serem de natureza muito diversa. Durante o perlodo experimental, houve ocorrencia de febre e diarreia nos animais, aos quais foi administrado Talcin, Terramicina e Enterobacter, alem de Ganaseg utilizado contra piroplasmose, de acordo com a prescrica do veterinario responsavel pelo rebanho do departamento.

Atraves da TABELA 06 pode-se observar como se deram as ocorrencias de doencas nos dois tratamentos estudados. 
TABELA 06 casos de febre, diarreia e numero de medicacoes durante o periodo experimental.

\begin{tabular}{cccc} 
Tratamento & $\begin{array}{l}\text { Casos de } \\
\text { Febre }\end{array}$ & $\begin{array}{l}\text { Casos de } \\
\text { Diarreia }\end{array}$ & $\begin{array}{l}\text { Numero de } \\
\text { Medicacoes }\end{array}$ \\
\hline II & 6 & 8 & 35 \\
\hline
\end{tabular}

Tratamento I - Baias Individuais; Tratamento II - Baias coletivas

Como pode ser observado, ocorreram doze casos de diarreia nas baias coletivas, provavelmente devido ao mais facil contagio entre os animais e tambem ao fato de, na media, serem animais mais jovens do que os criados em baias individuais. De acordo com RADOSTITS (1975), a diarreia em bezerros edoenca de natureza complexa. E na verdade um sinal clinico de disfuncao intestinal, um mecanismo de reacao do trato intestinal caracterizada por uma hipersecrecao e reducao na absorca intestinal que provoca perda de liquido, eletrolitos e nutrientes. APPLEMAN \& OWEN (1975) citam que a diarreia pode ser apontada como uma das principais causas de mortalidade de bezerros nos EUA. A total prevencao da diarreia e diflcil, se nao impossivel. Esta reacao pode ser causada por enteropatogenos como a Eccolli e salmonella sp, por viroses como a chalmydia $\$$ sucedaneo de leite com proteinas desnaturadas ou ainda por alimentacao excessiva. Segundo RoY (1970b), o fato dos animais se sugarem, fato observado nas baias coletivas, aumenta a incidencia de infeccoes e diarreias e o autor comenta ainda que os casos de diarreia decrescem quando o animal passa a ter uma dieta mais solida. 
os casos de ocorrencia de febre na apresentaram diferenca aparente entre os tratamentos, o que esta de acordo com - resultado encontrado por WARNICK et alii (1977). Quanto ao numero de medicacoes, foram efetuadas 47 no Tratamento II, enquanto que no Tratamento I efetuou-se 35 , isto em funcao do maior numero de caso de diarreia ocorrido no Tratamento II.

FRIEND et alii (1985), analisando trabalhos experimentais, verificaram que a falta de adaptaca ao ambiente e fatores estressantes neste ambiente podem fazer com que a resposta imunologica dos animais seja aquem do esperado, tornando-os mais suceptlveis a doencas. FRIEND et alij (1985) encontraram algumas diferencas fisiologicas entre animais criados nos dois tipos de baia: os de baias individuais apresentaram um menor numero de leucocitos do que os animais criados em baias coletivas. 


\section{4- Comportamento}

4.4.1. Alteracoes nas posicoes em pe e deitados.

A FIGURA 04 mostra os tempos totais, em minutos, em que os animais permaneceram em pe nas mais diversas atividades, nas diferentes idades, e a TABELA 07 a andise de variancia para tempo total em pe. Verifica-se que houve diferenca significativa no tempo em que os animais pemaneceram em pe. Os bezerros alojados nas baias individuais pemaneceram menos tempo em pe do que os animais das baias coletivas. Pode-se verificar ainda que ocorreu na sexta semana de idade uma tendencia de aumento no tempo dispendido em pe nos dois tipos de baias estudados, e que na oitava semana os bezerros pemaneceram deitados por mais tempo. Essa observacao esta de acordo com o trabalho de KERR \& wood-GUSH (1987) onde foi relatado que apos a oitava semana de idade os animais permaneceram menos tempo em pe. O acrescimo observado no tempo que os animais passaram de pe da terceira ate a sexta semana pode ser explicado pela curiosidade inerente aos animais jovens. Inicialmente calmos, os animais văo tornando-se mais ativos e curiosos com o decorrer da idade, voltando posteriormente a se acalmar. Este fato pode ser bem observado quando os animais eram soltos no patio, onde passavam uma hora diariamente. Nas primeiras semanas do experimento, ate aproximadamente a sexta semana, era normal ver os animais explorando e cheirando tudo o que estivesse ao seu redor. com o pasar do tempo houve tendencia dos animais deitarem-se no patio sem que se verificassem quaisquer sintomas de enfermidade, 
indicando terem se tornado maig calmos. Este tipo de comportamento refletiu-se tambem dentro das baias e as curvas da FIGURA 04 o estao ilustrando.

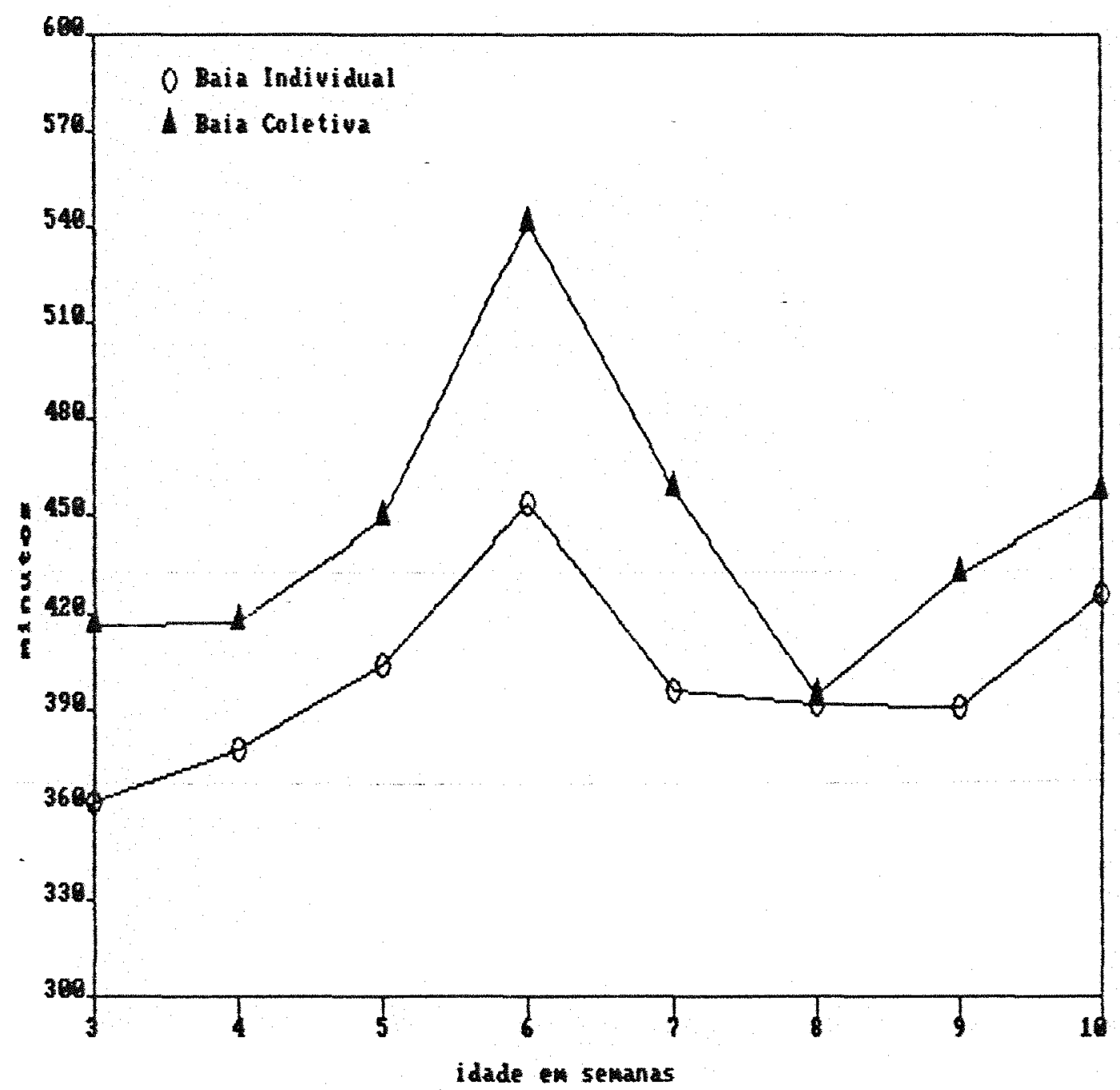

FIGURA 04 - Tempo que os animais permaneceram em pe durante o dia, desenvolvendo qualquer atividade. 
TABELA 07 - Analise de variancia para o tempo total em que os animais permaneceram em pe durante o dia.

CAUSAS DE UARIACAO

G. L.

S.Q.

Q.M.

E

$\begin{array}{lrrrr}\text { Baias } & 1 & 55922,418 & 55922,418 & 5,404 \text { * } \\ \text { Reglduo (A) } & 10 & 103478,587 & 10347,858 & \end{array}$

Parcelas

Dias

Baia*Dia

Residuo (B)

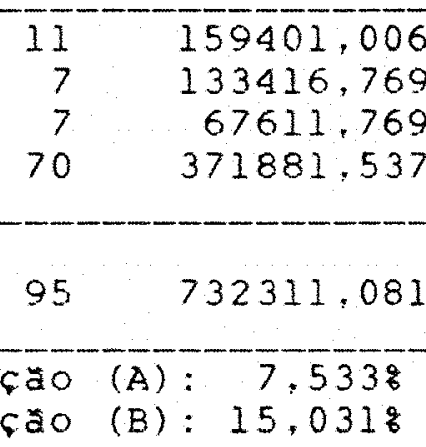

coeficiente de variacá (B): $15,031 \%$

A FIGURA 05 mostra o numero de vezes em que os animais levantaram-se durante o dia. Pode-se notar que, com o passar do tempo, os animais criados em baias individuais nao alteraram de forma drastica o comportamento, mas que nas baias coletivas ocorreu uma tendencia vislvel de aumento no numero de vezes em que os animais se levantaram com o decorrer do experimento, isto talvez se deva ao espaco vital oferecido aos animais e ao fato de nas baias indiviouais nao haver interferencia de um animal com o outro. Pode-se observar na FIGURA 01 que os animais nas baias coletivas tinham a sua disposicao $4.03 \mathrm{~m}^{2} / \mathrm{cab}$, enquanto os animals das baias individuais dispunham de $1,89 \mathrm{~m}^{2} / \mathrm{cab}$. 0 menor espaco dispontvel e a ausencia de companheiros deve ter tido efeito sobre a movimentacao dos animais criados individualmente. VERGA et ali (1985) atribuem a maior inatividade de seus animais um maior ganho de peso, o que nao pode ser comprovado neste experimento. WARNICK et alii (1977), por outro lado, nao 
encontraram diferenca no tempo em que os animais passaram deitados quando compararam animais que dispunham de $10 \mathrm{~m}^{2} / \mathrm{cab}$ em baias coletivas com $2,6 \mathrm{~m}^{2} / \mathrm{cab}$ em individuais.

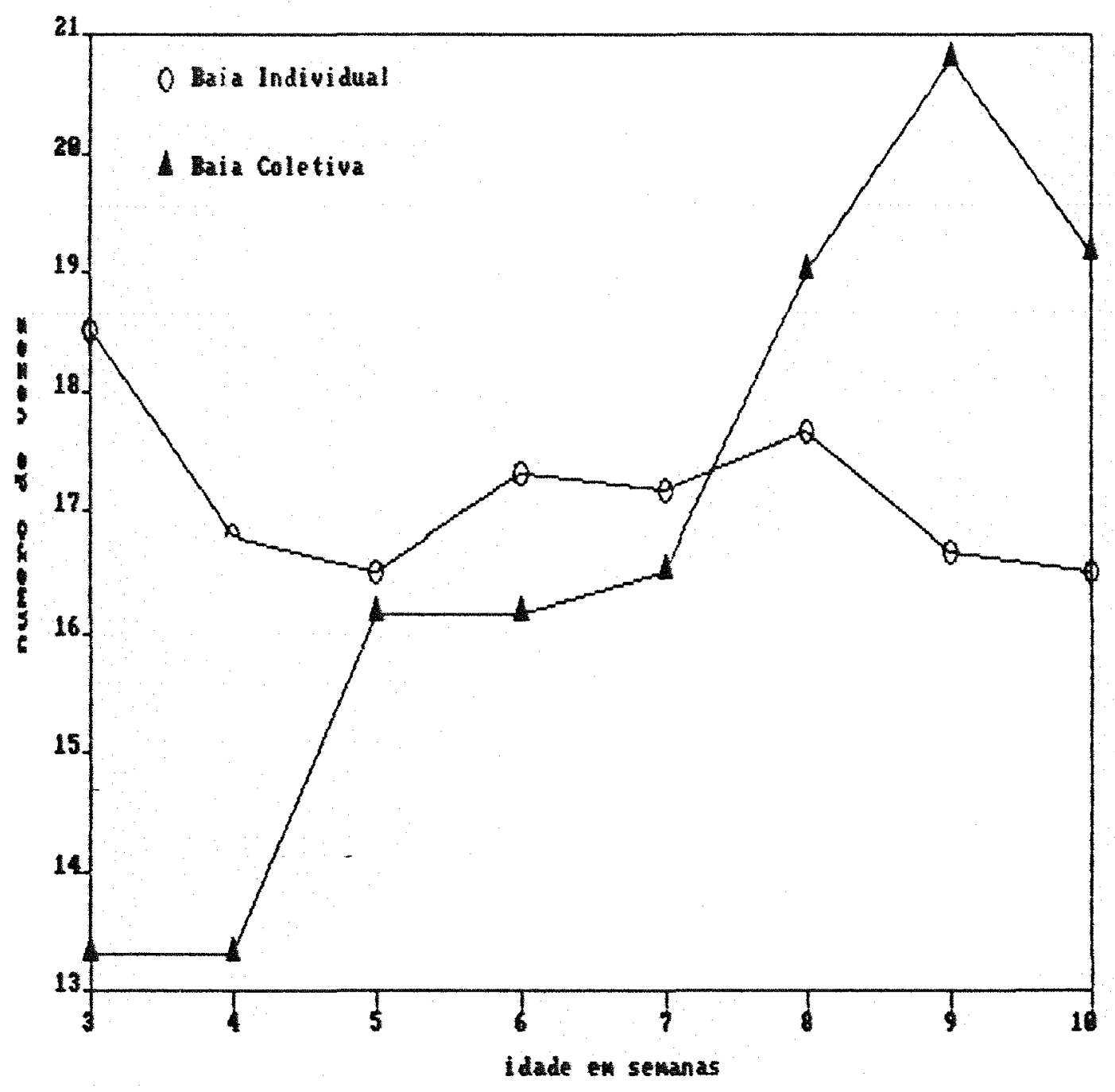

FIGURA 05 -Numero de vezes que os animais levantaram no dia.

4.4.2. Principais atividades

Apos a observacao de todas as atividades desenvolvidas pelos animais ao longo dos dias, foram separadas aquelas que eram desenvolvidas com maior frequencia, e por isso chamadas de atividades principais. A distribuicao dessas atividades durante 0 
dia, nas diferentes idades, pode ser vista na fIGURA of para as baias individuais, e na FIGURA 07 , para as baias coletivas. Pode ser verificado que durante a maior parte do dia, em ambos os tratamentos, os animais estao envolvidos com essas atividades.

Nas TABELAS 08 e 09 tem-se o tempo percentual qasto em cada uma destas cinco atividades.

TABELA 08 - Percentagem do tempo gasto nas principais atividades diarias nas Baias Individuais.

\begin{tabular}{|c|c|c|c|c|c|c|c|c|}
\hline \multirow[b]{2}{*}{ ATIUIDADE } & \multicolumn{4}{|c|}{ Idade em } & \multicolumn{2}{|l|}{ semanas } & \multirow[b]{2}{*}{9} & \multirow[b]{2}{*}{10} \\
\hline & 3 & 4 & 5 & 6 & 7 & 8 & & \\
\hline & & & & 8 & & & & \\
\hline Ruminando & 8,26 & 16,49 & 18,56 & 19,53 & 19.57 & 10,61 & 12,71 & 17,53 \\
\hline Comendo & 6,65 & 10,63 & 10,64 & 14.77 & 13 & 11,65 & 13,77 & 14,43 \\
\hline Deitado & 39,60 & 33,73 & 34.39 & 31,81 & 37,80 & 41,75 & 40,14 & 37,34 \\
\hline Dormindo & 25,02 & 20.95 & 16,61 & 16.37 & 12,50 & 19,72 & 17,83 & 15,19 \\
\hline $\mathrm{Em}$ pe & 4.51 & 5,09 & 5.47 & 4,88 & 4,67 & 6,44 & 5,97 & 6,39 \\
\hline outras & 15,95 & 13,11 & 14,23 & 12,64 & 11,93 & 9,83 & 9,58 & 9,11 \\
\hline
\end{tabular}

TABELA 09 - percentagem do tempo gasto nas principais atividades diarias nas Baias coletivas.

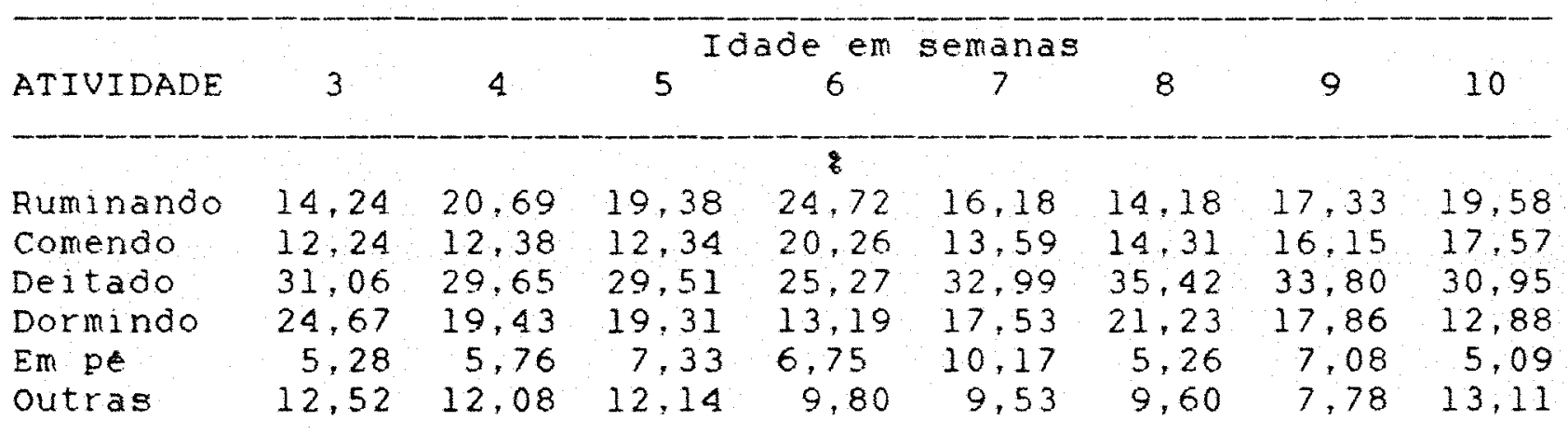




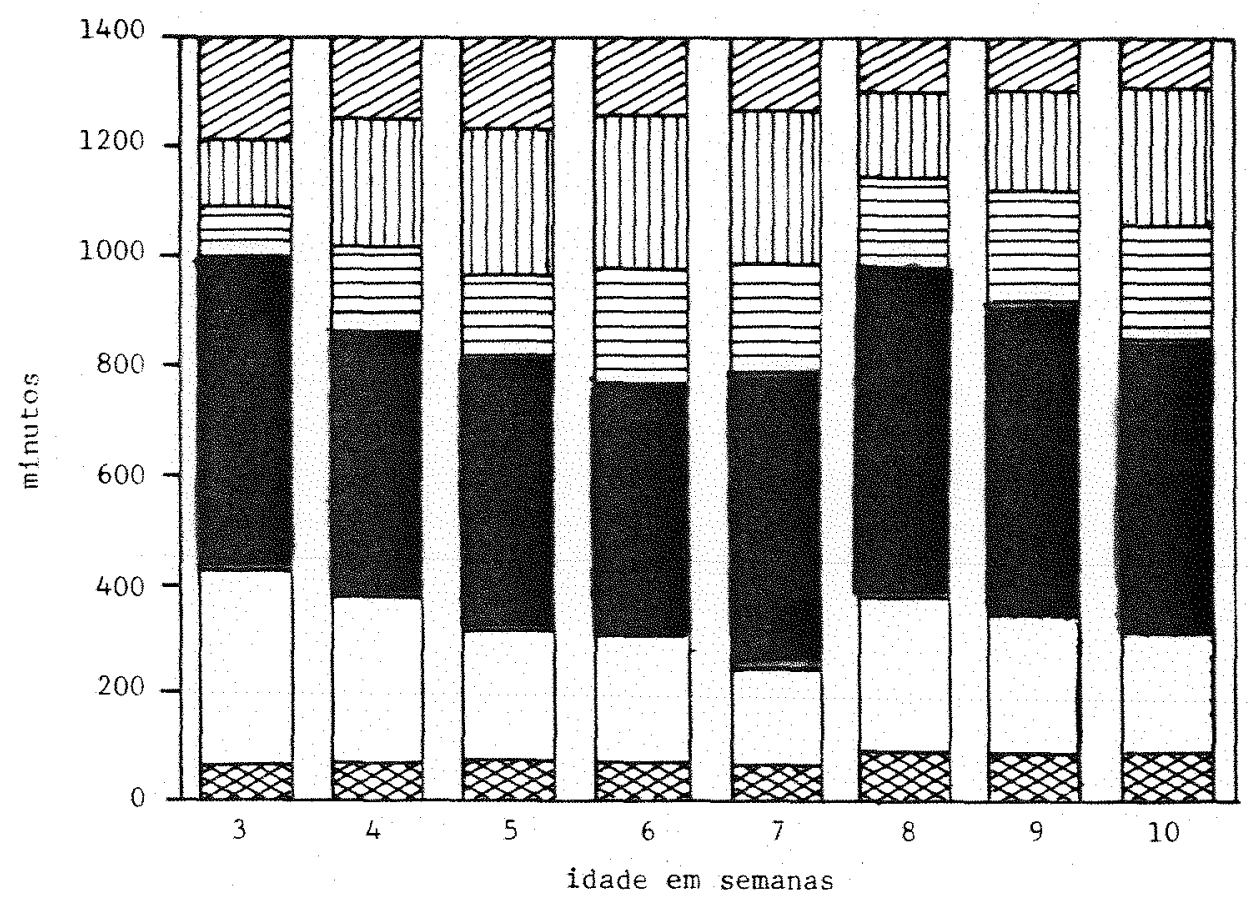

LEGENDA

$Q 8$ outras

DIIII Ruminando

$E$ Comendo

- Deitado

$\square$ Dormindo

Repouso em pi

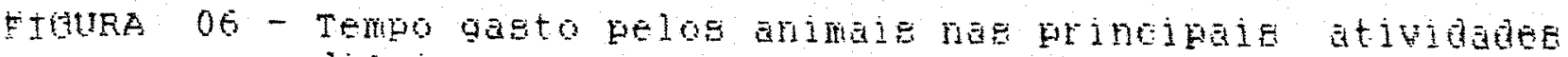

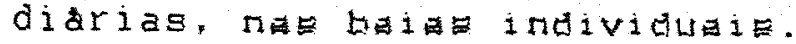

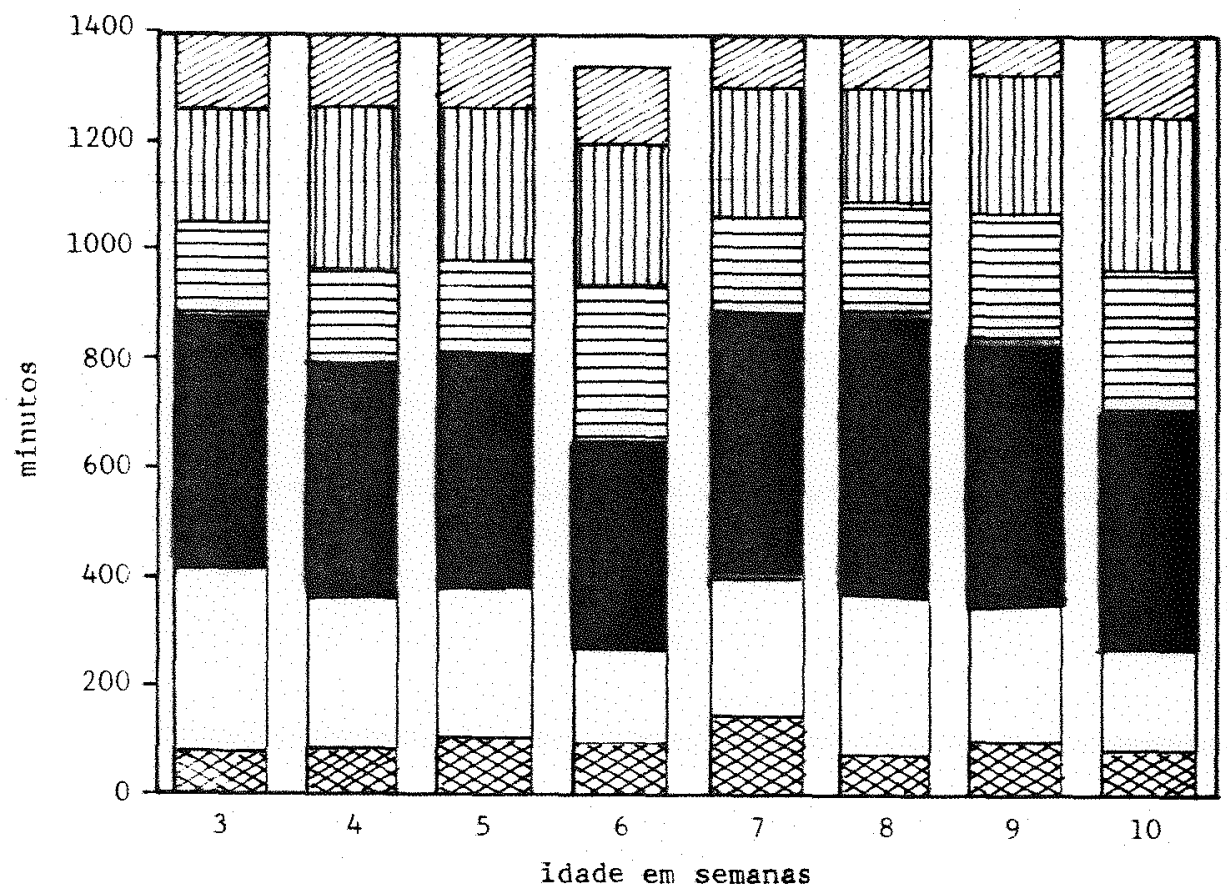

LEGENDA

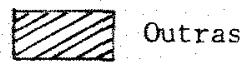

IIIIIIIII Ruminando

$\rightleftharpoons$ Comendo

Deitado

$\square$ Dormindo

Repouso em pé

FIGURA 07 - Tempo gasto pelos animais nas principais atividades ditrias, nas baias coletivas. 


\subsubsection{Ruminacao}

A atividade de ruminar, de acordo com luCCI (1989), pode iniciar-se a partir da sequnda semana de vida, quando os bezerros ja apresentam um sistema nervoso que a comanda completamente. Nas TABELAS 08 e 09 nota-se que nas baias individuais esta atividade alterna-se entre a segunda e a quarta atividade mais desenvolvida e nas baias coletivas fica entre a sequnda e a terceira. A partir da quarta semana de vida, nas baias individuais, foi verificada uma media de $16,42 \%$ do tempo diario dos animais gasto com a atividade de ruminacao, e nas baias coletivas 18,87\%. Esses dados estao de acordo com o percentual encontrado por KERR \& WOOD-GUSH (1987), segundo os quais bezerros confinados passam de 10 a $20 \%$ do seu tempo ruminando. Bezerros holandeses com idades entre 6 e 9 meses ruminaram por aproximadamente 28,02 do do dia ( MARIN, comunicacăo pessoal). CAMARGo (1988) trabalhando com animais adultos confinados, da raca holandesa, registrou que os animais passaram 31,03\% do tempo diario ruminando, ou seja com o desenvolvimento dos ruminantes ho um aumento no tempo diario dispendido em ruminaca.

Na FIGURA 08 observa-se que nao houve um efeito muito acentuado dos tipos de baias sobre o tempo gasto em ruminacao. A figura apresenta curvas a partir da idade de tres semanas. No entanto, em animais observados desde a sequnda semana de vida, ja era possivel notar sinais de ruminacao. Os bezerros ruminavam por curtos periodos de tempo. sempre quando deitados e com 0 ambiente tranquilo. Verifica-se, pela observacao do ortfico, um pico no tempo de ruminacao ocorrido na sexta semana para as baias 
coletivas, sequido de reducao: nas baias individuais o pico ocorreu na setima semana. LUCCI (1989) relatou trabalhos onde encontrou uma curva de tempo de ruminacso muito semelhante d obtida no presente trabalho quando forneceu a bezerros leiteiros leite, racao inicial e feno "ad libitum" como alimentacao.

WEBSTER et ali1 (1985) nao encontraram diferenca na idade de aparecimanto da ruminacao entre bezerros criados em baias individuais e coletivas.

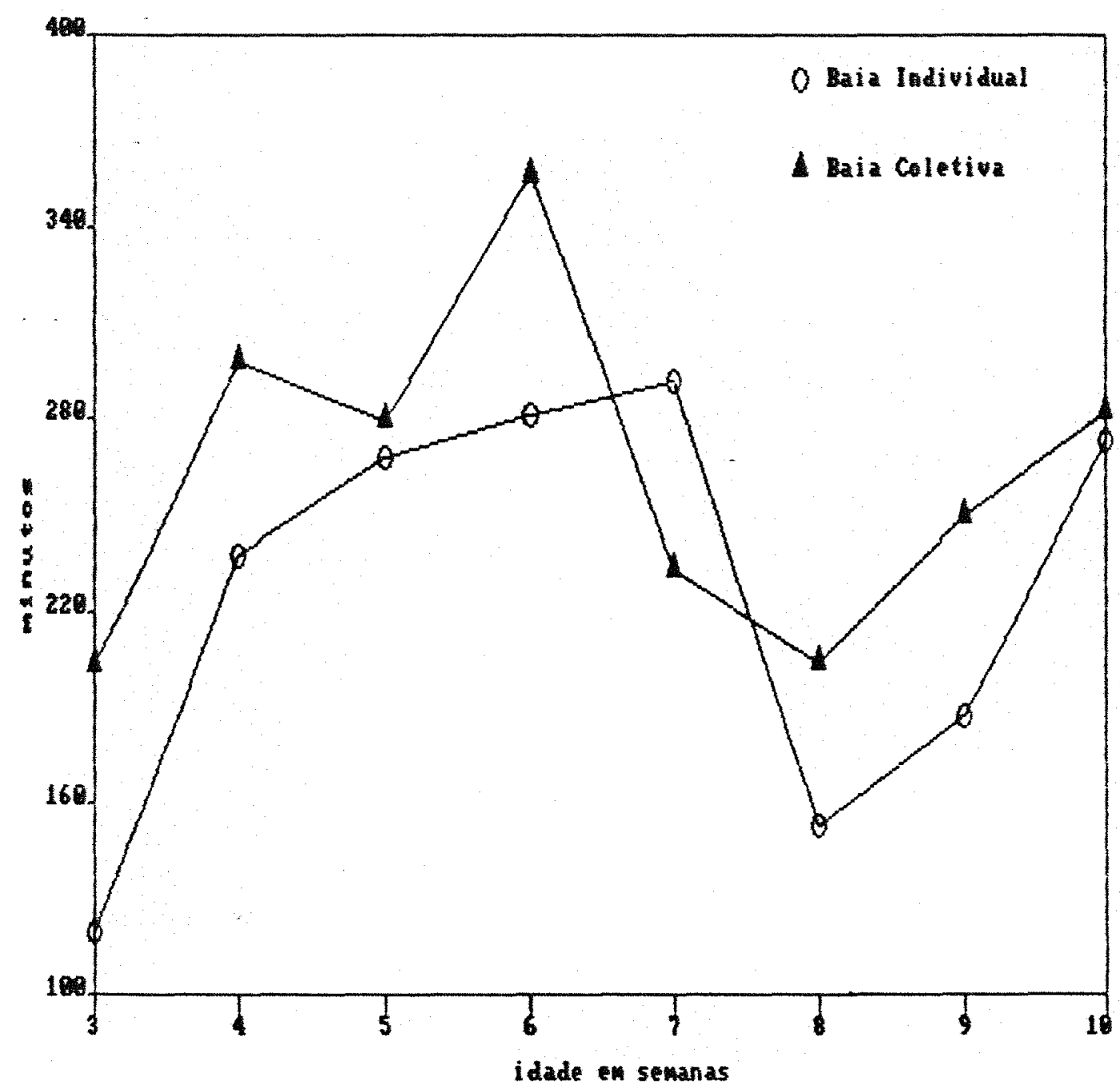

FIGURA 08 - Tempo que os animais passaram ruminando durante o dia. 
O numero de vezes em que o animal iniciou a atividade de ruminar pode ser visto na FIGURA 09, que tem suas curvas bastante semelhantes d da FIGURA 08. O numero de periodos ruminando, encontrados para os bezerros no presente experimento e demonstrado na FIGURA 09 , concorda com informacoes de HAFEZ (1970) que observou de 15 a 20 pertodos diarios de ruminacao por animal.

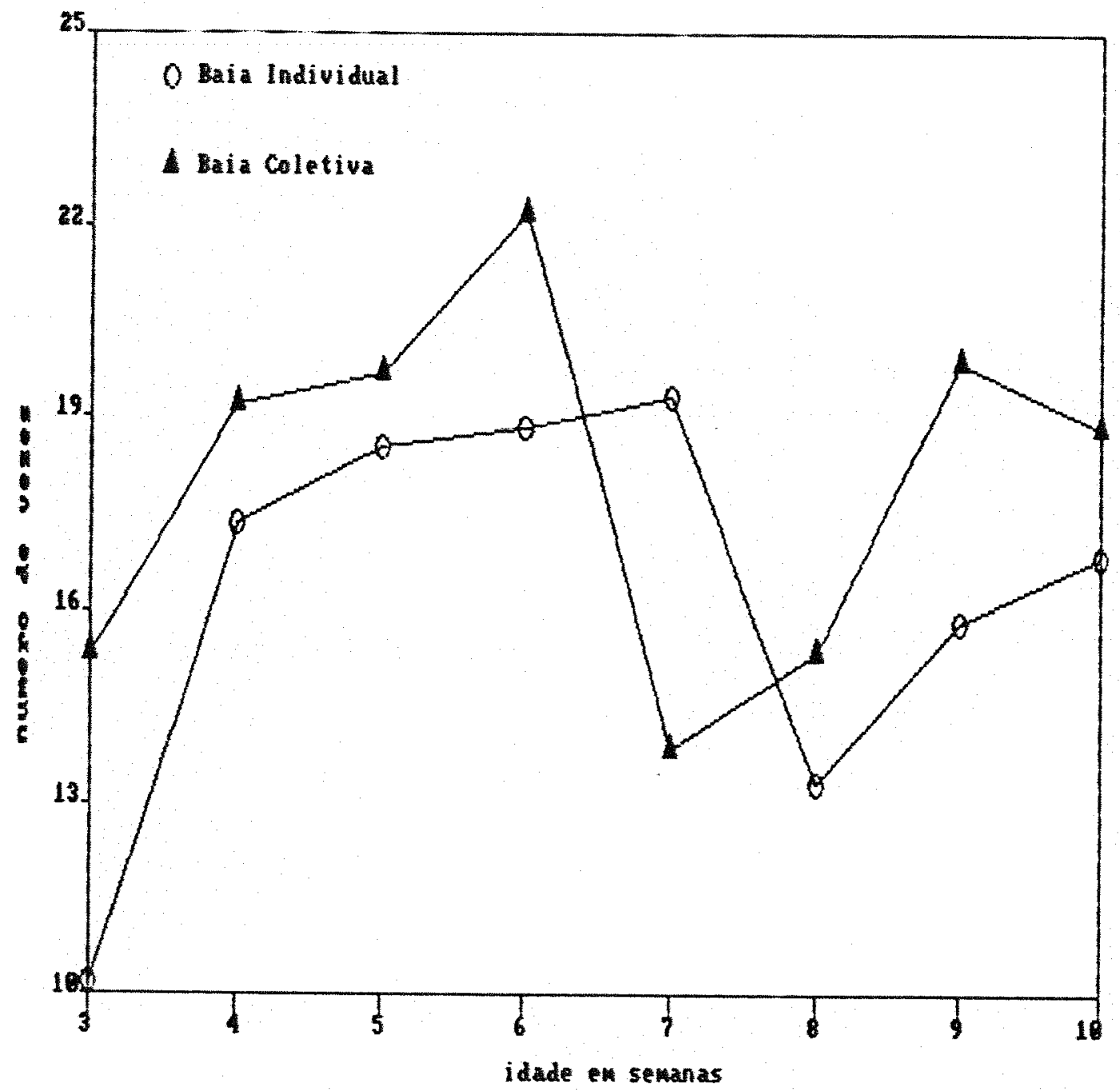

FIGURA 09 - Numero de vezes em que os animais ruminaram $4.4 \cdot 2 \cdot 2$. Comendo Sob este titulo estao somadas as sequintes atividades: comendo volumoso em pe e deitado e comendo concentrado. 
Verifica-se atraves das tABELAS 08 e 09 que os animais, durante o perlodo estudado, passaram mais tempo ruminando do que se alimentando e bebendo, fato esse inverso ao verificado por WEBSTER et alil (1985), em estudos realizados com bezerros de duas a quatorze semanas de idade, e por MARIN (comunicacao pessoal) com bezerros holandeses de seis a nove meses de idade. Ambos os autores, no entanto, encontraram pequenas diferencas entre os tempos comendo e ruminando, com alouma predominancia da alimentacáo. HAFEZ (1970) comentou que animais adultos em pastejo ruminam por tres quartos do tempo de pastejo.

Pode-se explicar a tendencia dos animais se alimentarem por menos tempo em sistema de criacao confinada, pois tendo 0 alimento a sua disposicao, sem necessidade de procura-1o, o animal alimenta-se mais rapidamente despendendo um menor percentual de seu tempo diario nesta atividade. o que tambem foi verificado por CAMARGo (1988), que encontrou 31,038 do tempo diario gasto com ruminacao contra 21,788 do tempo gasto com alimentaca, quando estudou o comportamento de vacas leiteiras adultas criadas no sistema de "free-stall".

Na FIGURA 10 esta representada a curva do tempo em que os animais passaram em atividade de alimentacao. As diferencas entre tratamentos nao sao acentuadas. os animais das baias coletivas demonstraram uma tendencia de passarem mais tempo comendo, durante o periodo experimental. Este fato, no entanto, nao implicou em maior consumo de concentrado ou em maior ganho de peso por parte dos animais, como comentado anteriormente. WARNICK et alii (1977) nao encontraram diferenca sianificativa no 
tempo consumindo alimentos entre baias individuais e coletivas, mas relataram que animais criados em baias coletivas comecaram mais cedo a consumir feno e concentrado. MARIN (comunicacáo pessoal), observou que os bezerros criados em baias coletivas passaram 29,7\% do seu tempo comendo, e os de baias individuais gastaram $29,6 \%$ de seu tempo nesta atividade, diferenca nao significativa. WEBSTER et alij (1985) tambem nao encontraram diferenca sionificativa no tempo em que os animais passaram comendo quando compararam baias individuais e coletivas. Desta forma o tipo de baia nao teve influencia sobre o tempo gasto em atividades de alimentaca.

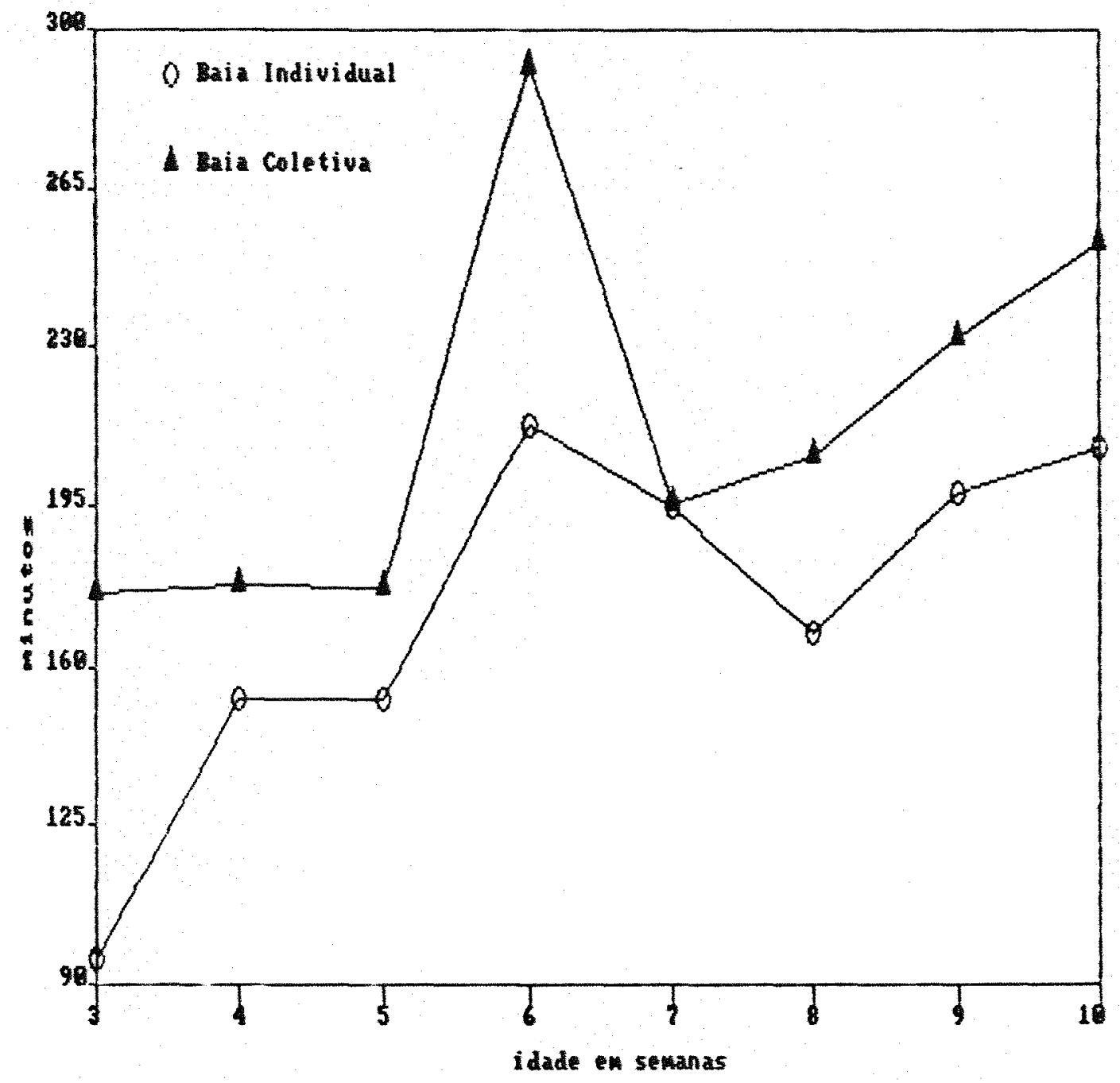

FIGURA 10 - Tempo que os animais passaram alimentando-se. 
A FIGURA 11 mostra quantas vezes os animaig comeram e beberam. Os animais das baias individuais iniciaram as atividades de alimentacaro por mais vezes, embora animais das baias coletivas tenham se alimentado por mais tempo. O fato dos animais ficarem sem companheiros elimina o efeito da competicao, o que proporciona maior liberdade para que se alimentem quando sentem necessidade. os animais que se alimentaram por mais vezes, emboram tenham dispendido menos tempo comendo, foram os que mais consumiram concentrado e tiveram maior ganho de peso. Talvez a explicacao para o fato seja um melhor aproveitamento do alimento devido a um maior parcelamento. Isto, no entanto. necessitaria de comprovaca.

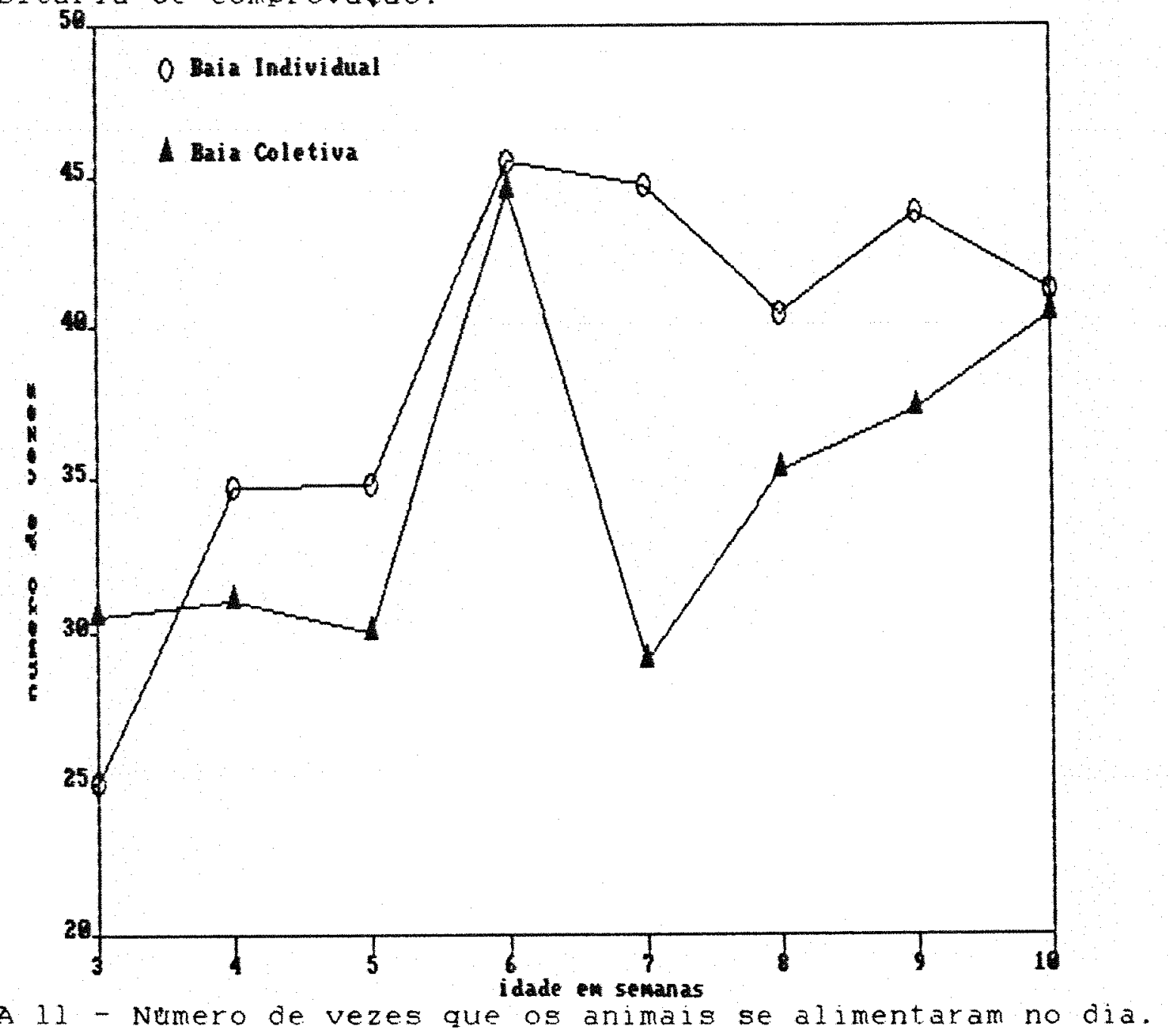

FIGURA 11 - Numero de vezes que os animais se alimentaram no dia. 
4.4.2.3. Deitado

Tempo deitado refere-se ao tempo em que o animal ficou deitado sem dormir ou desenvolver qualquer outra atividade. 0 tempo em que os animais passaram nesta atividade pode ser visto na FIGURA 12. Nesta atividade os animais passaram a maior parte do dia. De maneira oeral, mais de 30 do dia fol destinado ao repouso.

Animais das baias individuais ficaram deitados por mais tempo em todas as idades, talvez devido falta de estimulo que pode ser provocada pela presenca dos companheiros. WARNICK et a11 (1977) nao verificaram esta diferenca entre baias individuais e coletivas. so os animais criados em baias completamente isoladas e que permaneceram deitados por mais tempo, sem que isso afetasse o desenvolvimento. VERGA et alil (1985) encontraram uma relacao positiva entre tempo deitado e ganho de peso. WEBSTER et 릴 (1985) observaram que os animais criados em orupo passaram mais tempo deitados do que os animais em bajas individuais, mas relacionaram o fato ao tipo diferente de piso nos dois tratamentos.

As curvas da FIGURA 12 mostram-se de certa forma paralelas, ou seja, no decorrer da idade, estando em baias individuais ou coletivas, houve um decrescimo no tempo deitado ate a sexta semana de idade. A partir de entao, os animais passaram a ficar mais tempo deitados, e apos a oitava semana este tempo comecou a reduzir-se, tendencia ilustrada pela FIGURA 04. 


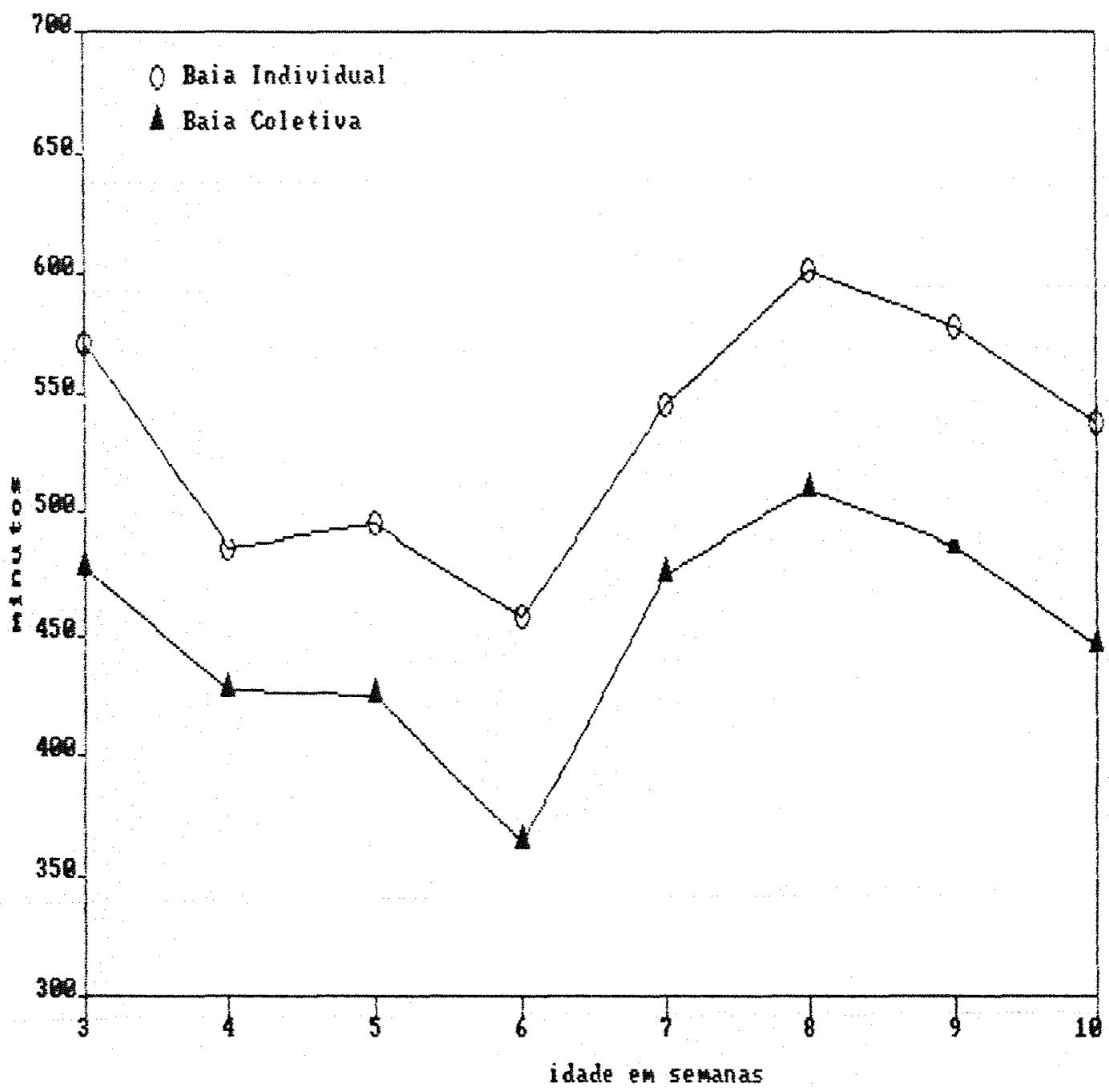

FIGURA 12 - Tempo em que os bezerros passaram deitados, sem
desenvolver nenhuma outra atividade. 4.4.2.4. Dormindo

- tempo em que os animais passaram dormindo pode ser vis to na FIGUAA 13 . 
Observa-se que nao houve orandes diferencas entre os dois tratamentos, embora os animais das baias individuais tenham passado mais tempo deitados, FIGURA 12, eles nao ficaram dormindo por mais tempo que os das baias coletivas. Sequndo a tendencia verificada na FIGURA 12, houve uma reducao no tempo dormindo, um aumento e uma nova reduca. Nas baias coletivas isto ocorreu na sexta semana enquanto que nas baias individuais esta reduca se verificou na na setima semana de vida. WEBSTER et alii (1985) constataram que a medida que os bezerros ficam mais velhos, pasam menog tempo deitados, assim como dormindo. No presente experimento esta afirmaga nä ficou muito bem evideneiaga guando analisou-se o tempo deitado sem dormir, mas pode ser percebida na FIGURA 13. Com o desenvolvimento dos animais houve uma reducaro no tempo que os animais passaram dormindo. MARIN (comunicacao pessoal), em seu trabalho com animais de seis a nove meses de idade, somou o tempo em que os animais passaram deitados sem desenvolver outra atividade com o tempo que passaram dormindo, e encontrou para baias coletivas 29,28 do tempo total e para baias individuais 31,1\%. No presente experimento, quando se somou o tempo deitado com o tempo dormindo de animais com dez semanas de idade, em baias individuais, obteve-se $52.5 \%$ do tempo nestas atividades, enquanto que nas baias coletivas este percentual foi de 44.08, como pode ser visto nas tabelas 08 e 09 , respectivamente. Isto confirma a afirmaca de WEBSTER et ali (1985). 


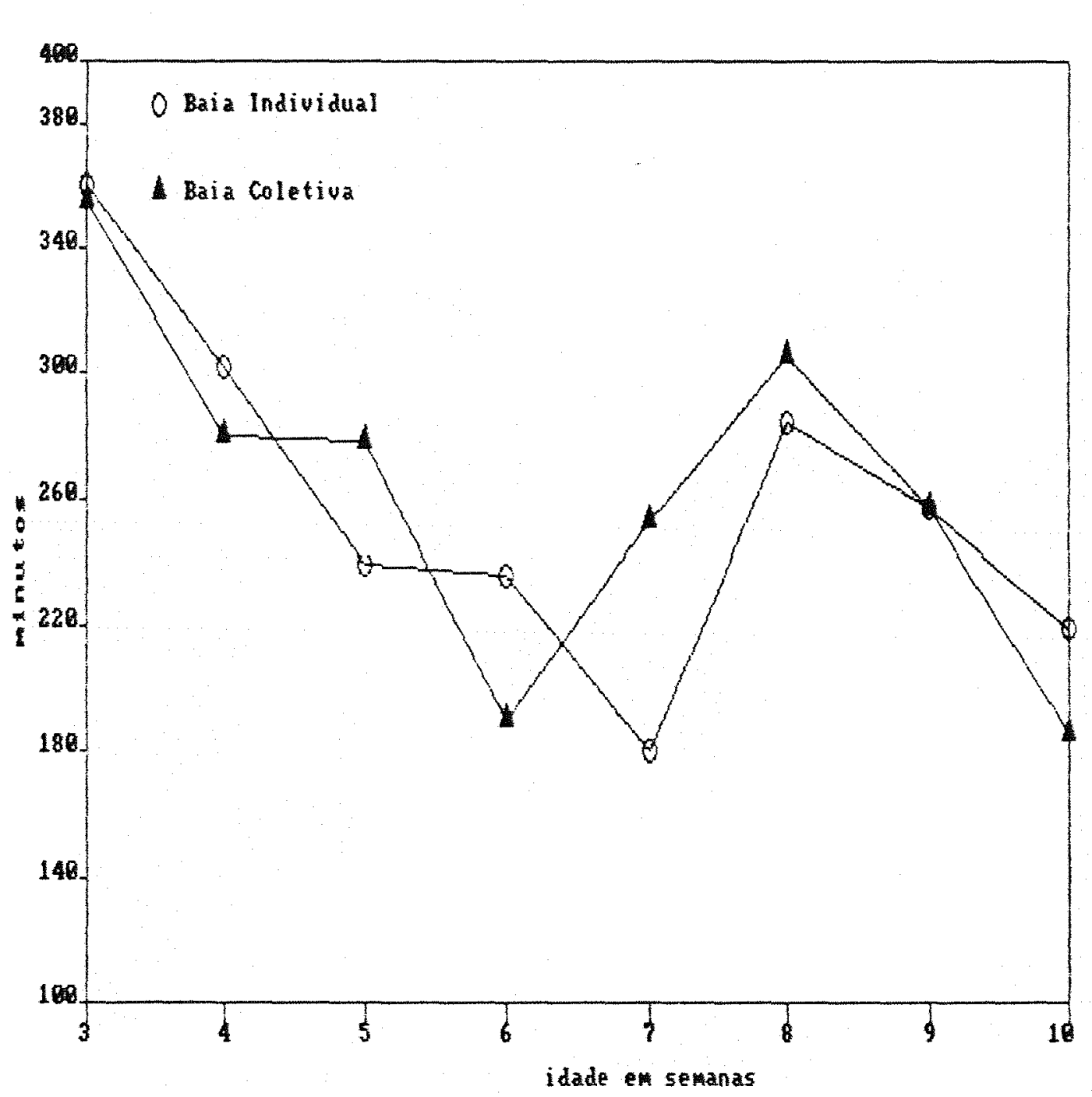

FIGURA 13 - Tempo em que os animais dormiram durante o dia.

$4 \cdot 4 \cdot 2 \cdot 5 . \mathrm{Em}$ pe

Esta atividade descreve o animal em pe, dentro da baia. sem desenvolver qualquer atividade. E a atividade na qual o animal dispendeu menos do seu tempo, dentre as cinco principais, e pode ser visto na FIGURA 14.

A medida em que os animais tornam-se mais velhos. verifica-se tendencia de ficarem mais tempo em pe, sendo que algumas flutuacoes neste tempo sao esperadas (KERR \& woOD-GusH, 1987). WEBSTER et ali 1 (1985), por outro lado, encontraram uma reduca no tempo em que os bezerros por eles observados ficaram 
em pe sem desenvolver qualquer outra atividade. Atraves da observacao da FIGURA 14 verifica-se nas bajas individuais uma tendencia dos animais aumentarem gradativamente o tempo em que passam de pe. Porem, verificam-se marcantes flutuacoes na curva do grafico correspondente as baias coletivas, o que pode ter ocorrido em funca de uma maior interacao entre os animais. Pode ser observado que os animais em baias coletivas frequentemente desalojam seus companheiros para ocuparem os seus lugares e deitarem-se e os animais desalojados ficam em pe durante alguns minutos antes de tornarem a deitar-se.

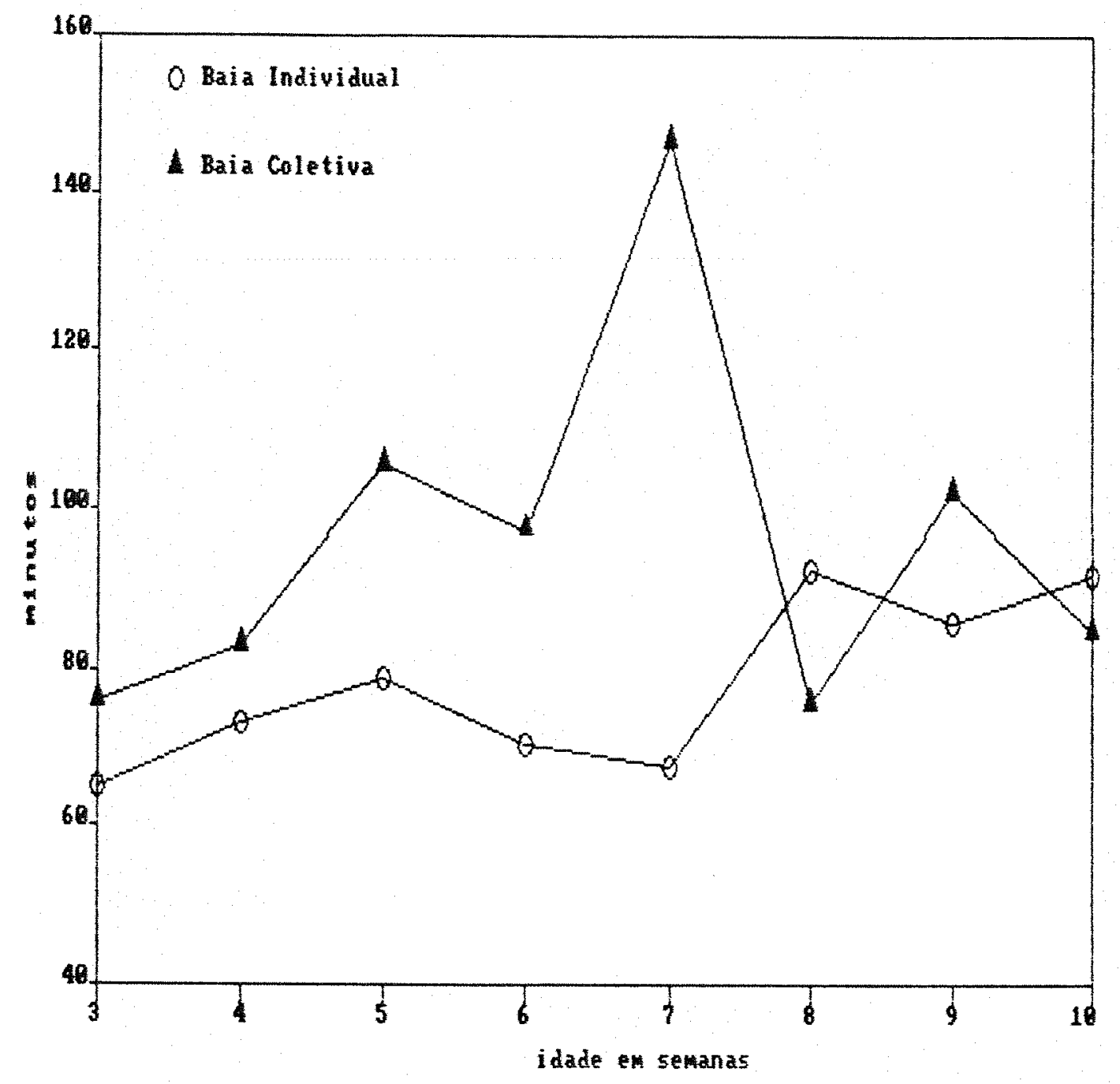

FIGURA 14 Tempo que os animais ficaram em pe, sem desenvolver qualquer atividade. 
4.4.3. Outras atividades

\subsubsection{Atividades sociais}

Foram consideradas atividades sociais as atitudes de: lamber objetos, lamber-se e lamber outros animais, atividade de sugar, atividade de andar, de brincar e de observar.

Atividades de brincar ou cabecear foram pouco reqistradas. No intcio do pertodo experimental ocorreram alguns registros, mas o numero foi tao pequeno que nao chegou a ser reqistrado.

A atividade de andar implica em busca de alimento, busca de melhor lugar ou posicao para deitar e a ida ate outros animais para se interagirem. Na FIGURA 15 pode ser visto o tempo em que os animais passaram andando dentro da baia e no patio. Animais mais jovens passam mais tempo andando e explorando lugares novos. A medida em que os animais ficam mais velhos tornam-se mais quietos e passam a deitar, mesmo no patio. os dois tratamentos nao diferiram muito quanto ao tempo andando. Apenas no intcio do periodo experimental houve uma tendencia dos animais criados em baias coletivas andarem mais. A explicacao para isto pode ser o fato das hajas coletivas oferecerem maior espaco por animal e haver maior interacao entre os animais. Esta tendencia e reduzida com o tempo ate a adolecencia. quando novamente incrementada devido ao impulso sexual. 


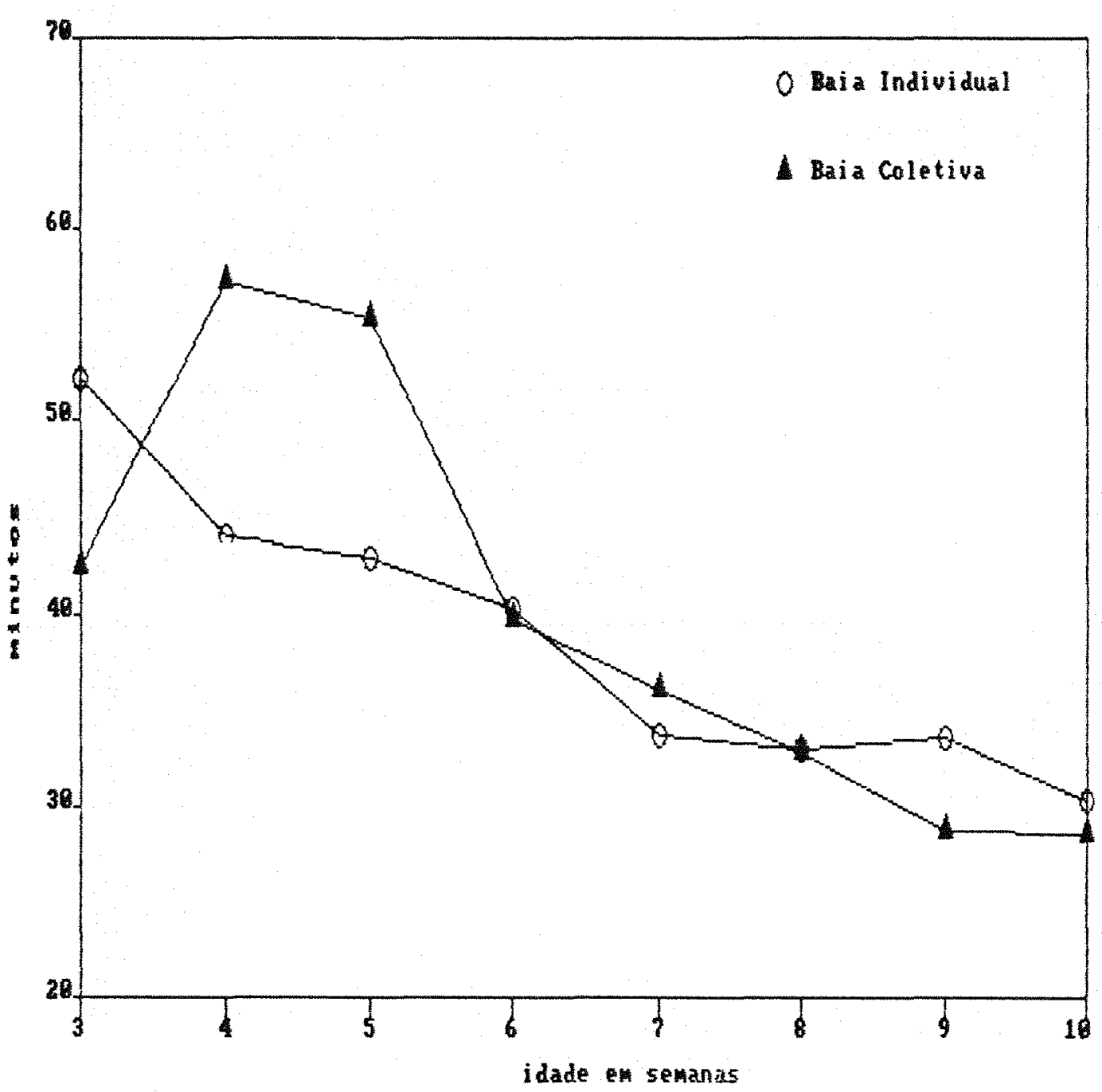

FIGURA 15 - Tempo que os animais passaram andando.

Na FIGURA 16 est inserido o numero de vezes em que os animais ficaram olhando para fora de suas baias. Pode-se observar atraves das curvas da FIGURA 16 que os animais alojados em baias individuais, quando mais jovens, passam mais tempo olhando para fora de suas baias do que os animajs das baias coletivas, o que e esperado, uma vez que animais criados individualmente nao tem os companheiros para se entreterem. por volta da sexta semana de idade, os animais das baias coletivas passaram a olhar mais tempo para fora das baias. Uma possivel razo poderia ser a espera do leite, ja que a quantidade fornecida nesta fase nao supria completamente suas necessidades. Torna-se, portanto, muito 
aquardado. Com seis semanas aproximadamente os animais das baias individuais foram desmamados. Apos esta fase houve novamente tendencia dos animas das baias individuais ficarem mais tempo olhando para fora de suas baias. Quando os animais tornam-se mais velhos a atividade de observar diminui, tambem de acordo com KERR \& WOOD-GUSH (1987).

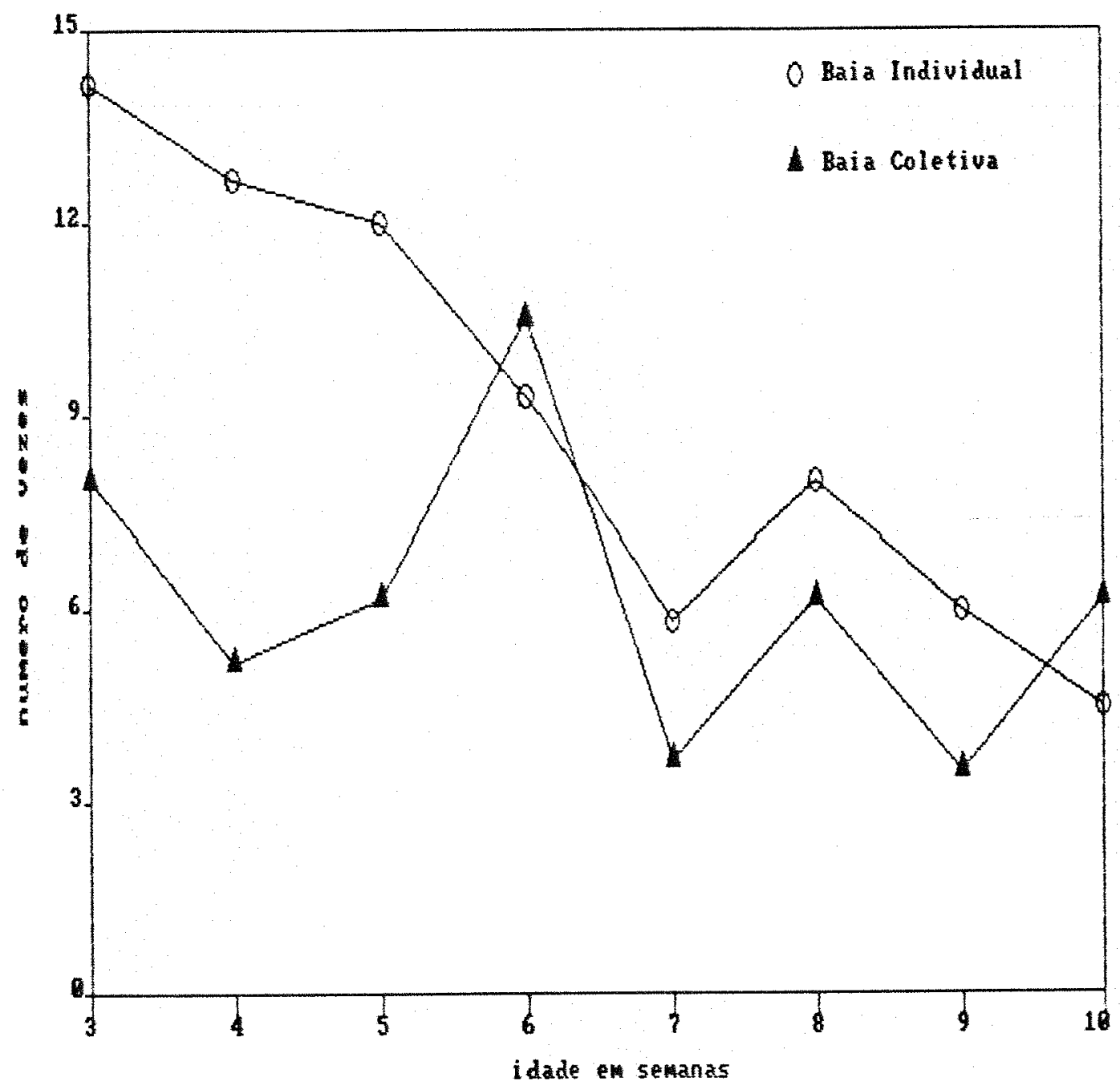

FIGURA 16 - Numero de vezes em que os animais olharam para fora de suas baias.

- ato dos bezerros sugarem-se mutuamente ou suoarem objetos, quando aleitados artifjcialmente, e um comportamento dos mais comuns e facilmente encontrado em rebanhos leiteiros que 
usam aleitamento artificial. Na FIGURA 17 aparece o tempo em que os animais das duas baias passaram sugando. Verifica-se que os bezerros das baias coletivas sugaram por mais tempo, e sugaram principalmente seus companheiros. Na FIGURA 18, onde esta representado o numero de vezes que passaram sugando, observa-se que embora os bezerros das baias coletivas tenham sugado por mais tempo, os animais das baias individuais sugaram mais vezes. Mas, como pode ser notado, em nenhum dos tratamentos este habito tornou-se um vicio, uma vez que este comportamento ocorria apenas apos o aleitamento e os animais nao o realizavam de uma forma compulsiva, mas sim por um curto periodo de tempo. Comportamento tambem verificado por WEBSTER et alii (1985).

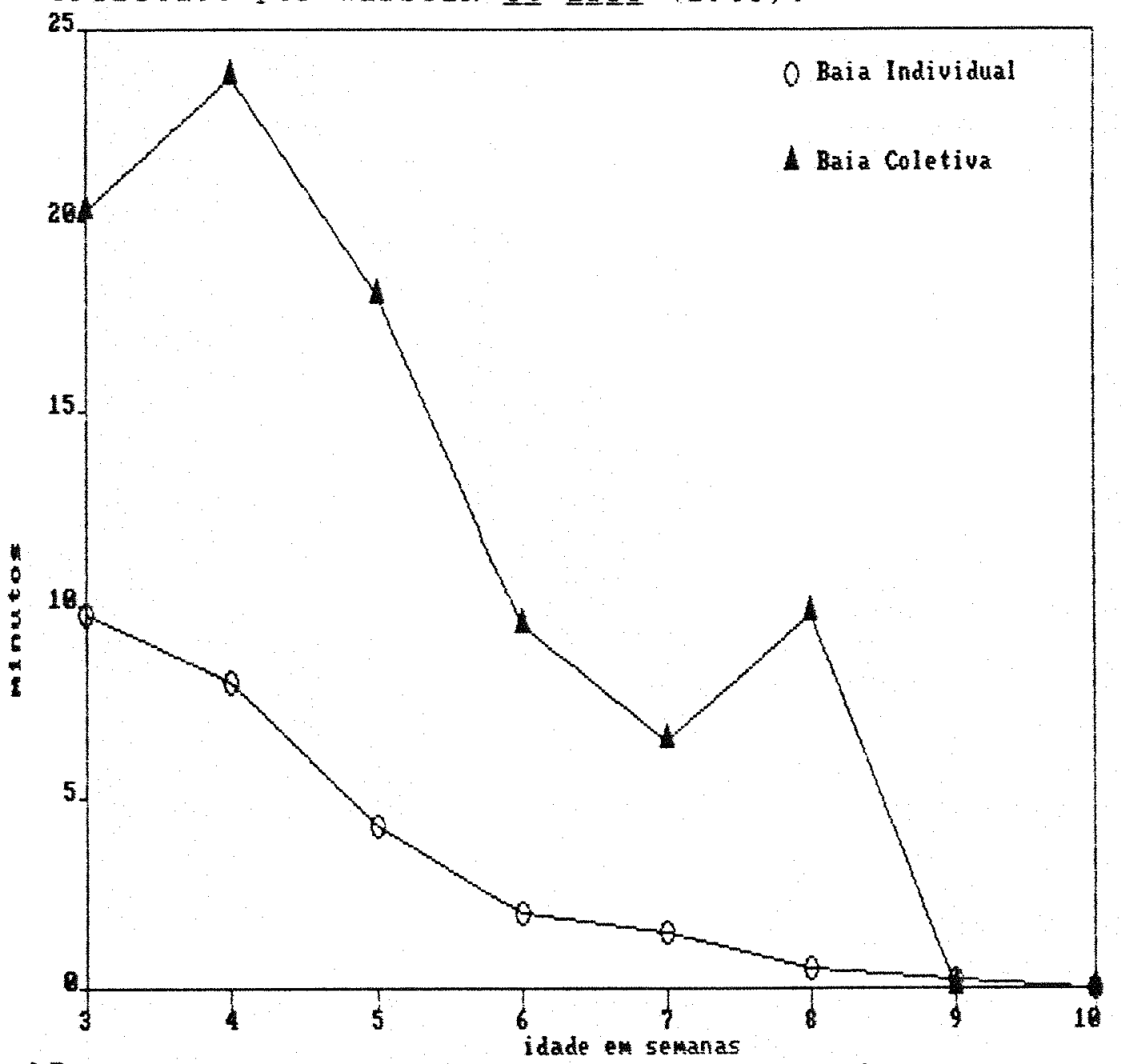

FIGURA 17 - Tempo que os animais passaram sugando. 


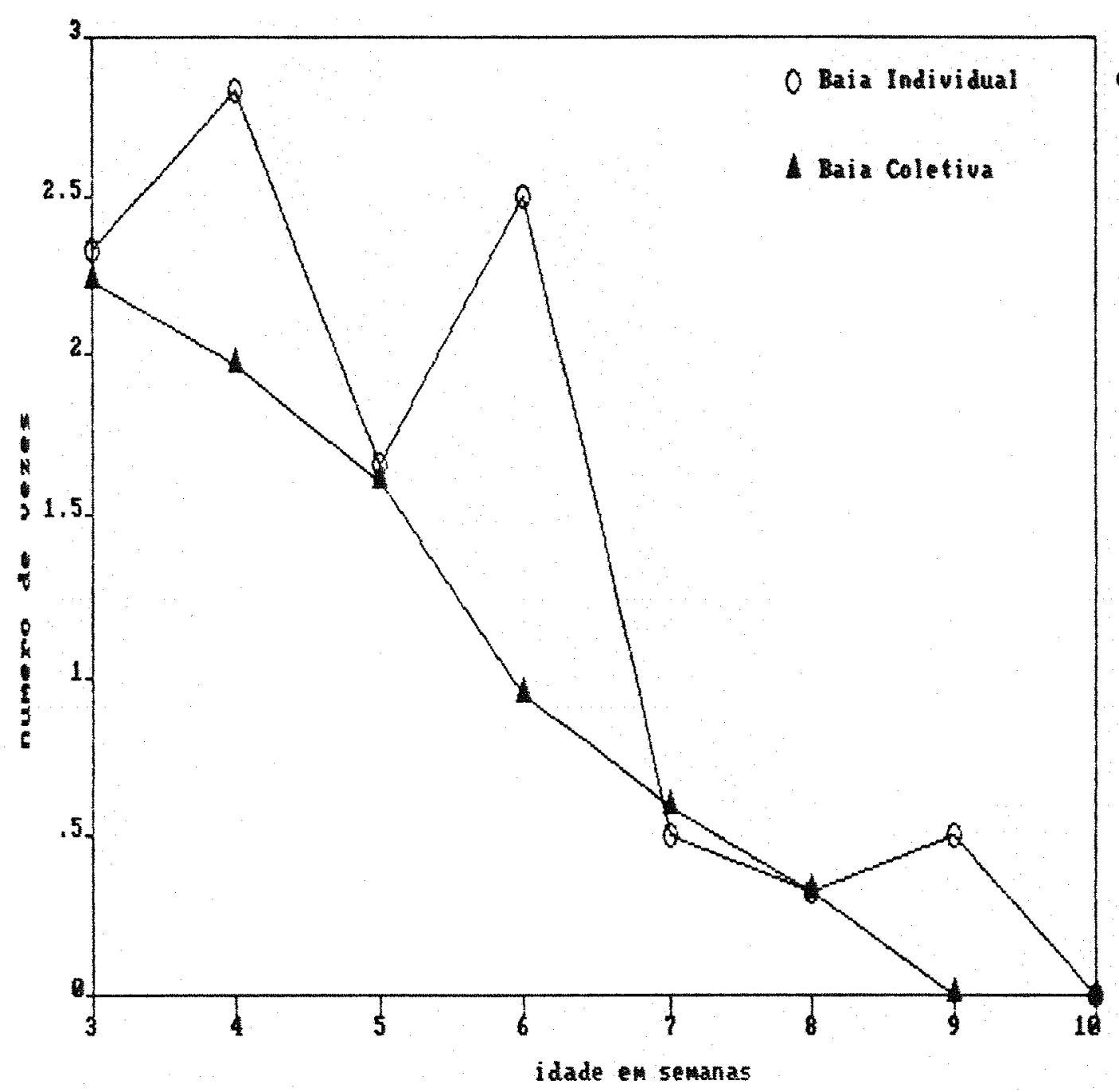

FIGURA 18 - Numero de vezes que os animais sugaram.

o ato de lamber em bezerros e um comportamento

inerente: todos os bezerros lambem. Eles podem lamber seus proprios corpos, objetos que os rodeiam ou seus companheiros, de acordo com SATO (1984).

No presente experimento, tanto os bezerros das baias coletivas quanto os das baias individuais passaram mais tempo lambendo seus proprios corpos do que objetos ou companheiros, como pode ser observado na FIGURA 19. De acordo com VERGA et al11 (1985), este comportamento indica que os animais estavam adaptados ao ambiente. O fato dos animais lamberem objetos ou companheiros mais do que seus proprios corpos, sao comportamentos deslocados, que indicam falta de adaptacao ao ambiente (VERGA et 
a1ii, 1985). Com a idade, o tempo total em que os animais passaram lambendo diminuiu, caso tambem descrito por sato (1984). que chamou a atencao para o fato de que o espaco d disposicáo dos animais era um fator que interfere sobre o tempo em que os animais passam lambendo-se. De acordo com o mesmo autor, o tempo em que os animais passam lambendo seus proprios corpos esta inversamente relacionado com o espaco que eles tem a sua disposica. Este fato foi verificado no presente experimento, pois os animais das baias individuais passaram mais tempo lambendo-se do que os das baias coletivas. os bezerros das baias individuais tambem passaram mais tempo lambendo objetos, embora o tempo em que os animais das baias coletivas passaram lambendo objetos tenha sido superior ao tempo em que lamberam seus companheiros.

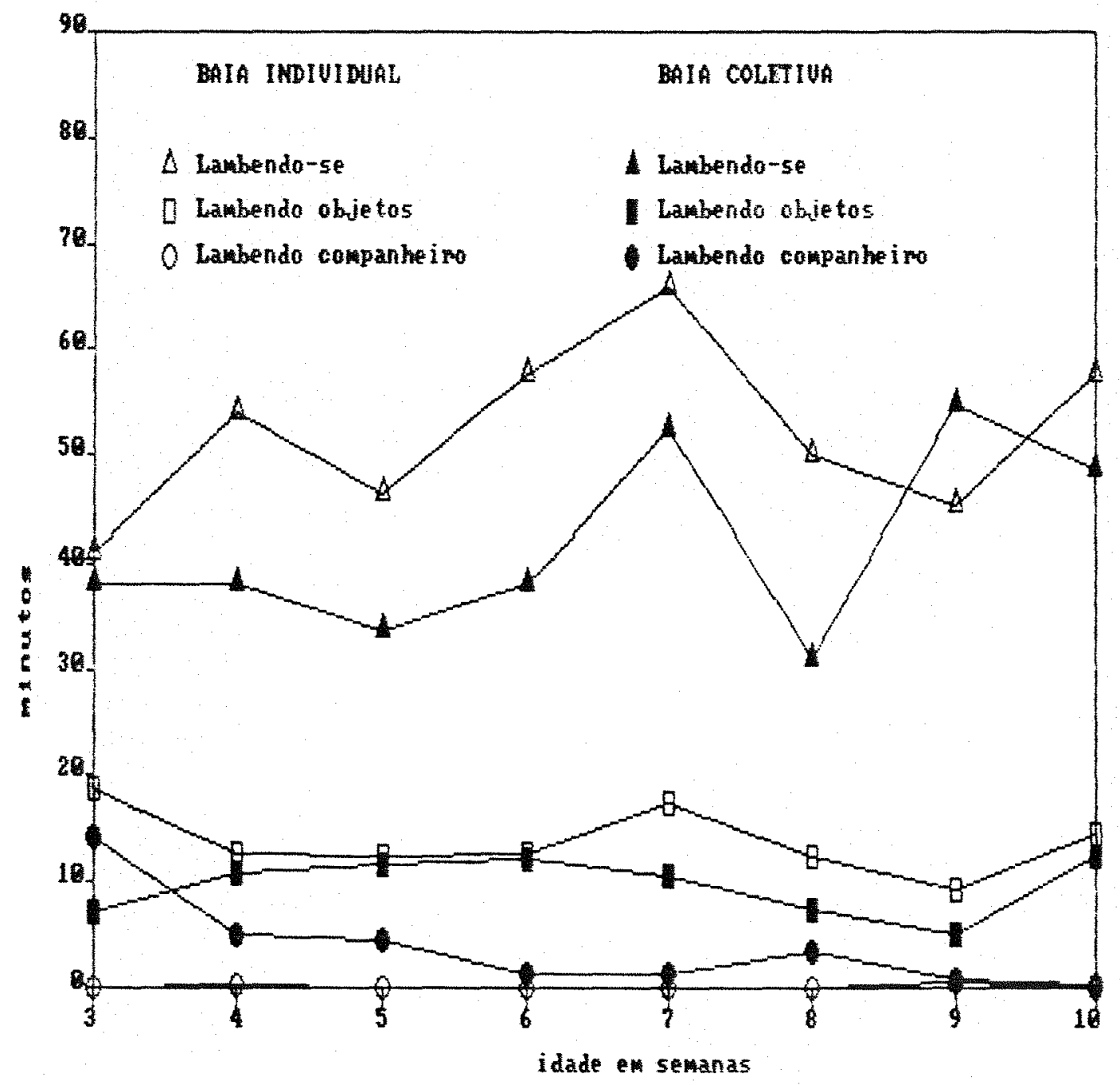

FIGURA 19 - Tempo que os animais passaram lambendo. 
o numero de vezes em que os animais lambiam-se apresentou tendencia de aumentar com a idade, e o numero de vezes lambendo objetos manteve-se aproximadamente constante, como demonstra a FIGURA 20.

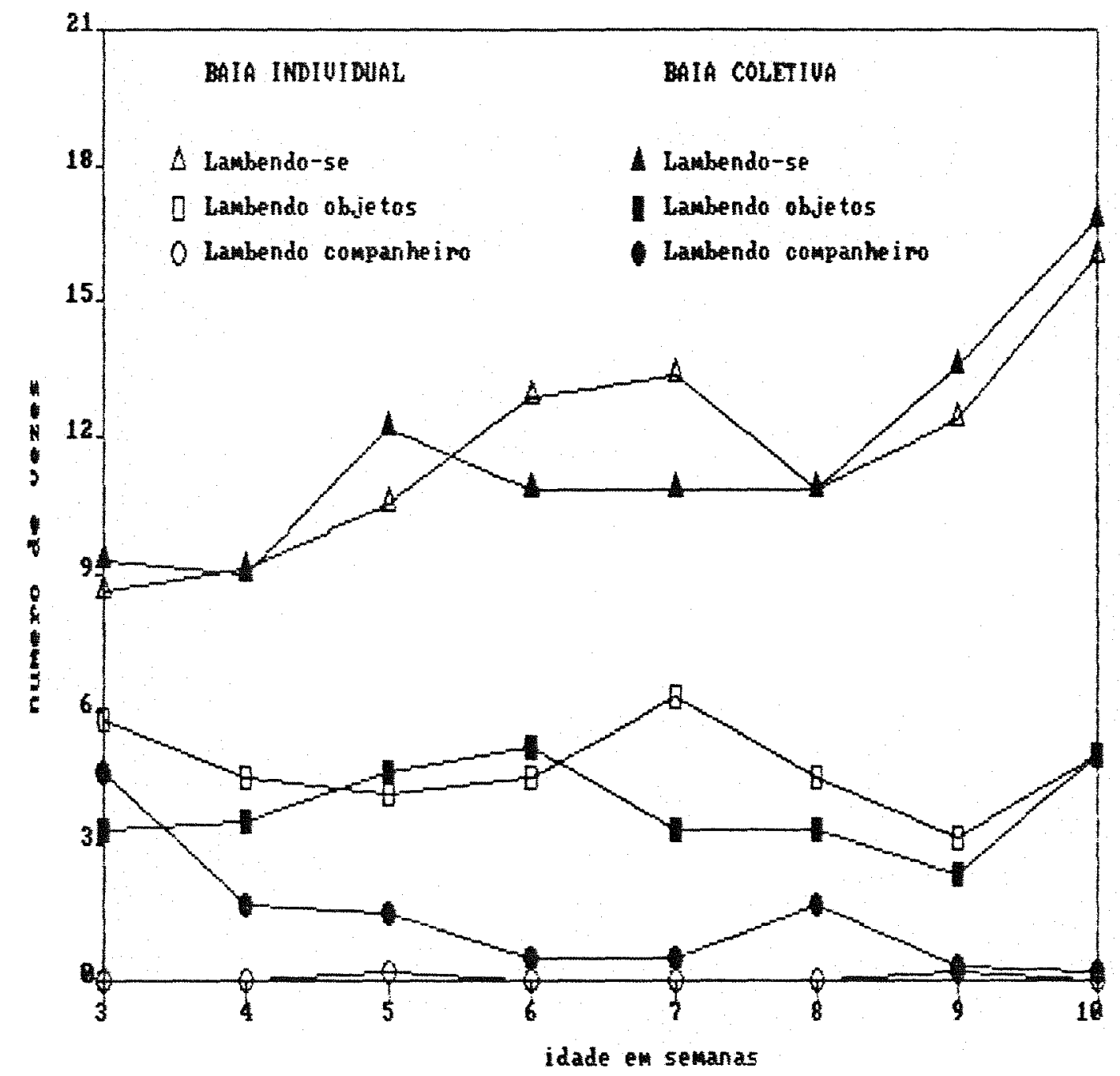

FIGURA 20 - Numero de vezes que os animais se lamberam. 1 amberam companheiro ou objetos. 


\section{CONCLUBOEB}

Com os resultados obtidos no presente trabalho, as sequintes conclusces podem ser tiradas:

1) Observou-se uma tendencia de na haver diferencas comportamentais entre bezerros alojados em baias individuaise bezerros alojados em baias coletivas.

2) As condicoes de criacao de bezerros foram favoraveis em ambos os tratamentos como mostrou o desempenho e o comportamento dos animais.

3) Na fase estudada, os bezerros gastaram a maior parte do tempo diario em atividades de repouso, $52,5 \%$ em baias individuais e 44,0 em baias coletivas. Este fato indica necessidade de um local apropriado para descanso, como cama.

4) Fica evidenciado que bezerros na fase de vida estudada podem ser criados tanto individualmente quanto em grupo. Seria necessario uma complementacao do presente experimento para se avaliar o efeito que o tipo de criacao possa vir a ter no desenvolvimento futuro dos animais, ouando estes passarem a fazer parte de grupos maiores. 


\section{REFERENCI AS BIBLIOGRÁFICAS}

APPLEMAN, R.D. 8 OWEN,F.G. Breeding, housing and feeding management. Journal of Dairy Science Champaign, 58 (3) $447-44$ Mar 1975.

ANDERSSON, M. Temporal graphical analysis of behaviour sequences. Behaviour Leiden 51 (1/2):38-48, Mar 1974.

ARAUE,C.W.; MICKELSEN C.H.; WALTERS J. L. EffeCt of earIY rearing experience on subsequent behaviour and production of holstein heifers. Journal of Dairy Science Champaign, 68 (4):923-9 Apr. 1985 .

BANKS, E. M. Behavioral research to answer question about animal welfare. Journal of Animal Science. Champaign 54 (2): $434-46$, Feb. 1982

BEILHARG, R. G. \& ZEEB,N. Social dominance in dairy cattle. Applied Animal Etholo8y Amesterdan 8 (1/2): 74-97, Jan. 1982.

BOGNER, H. Breeding for behavioral traits in cattle? Berliner und runchener Tieräzliche wochenschrift 95 (24) 476-7, 1982. Apud Animal Breeding Abstracts 51 (5) 330 , May 1983.

BROOM, D. M. \& LEAVER J.D. Effects of group rearing or partial on later social behaviour of calves. Animal Behaviour, London $26(4): 1255-63$, Nov. 1978 .

CAMARGO, A.C. Comportamento de vacas da raca holandesa em um confinamento do tipo "Free stall" no Brasil central. Piracicaba, 1988. 146p (Mestrado - Escola Superior de 
Agricultura "Luiz de Queiroz"/USP)

CAMPOS, O.F. Criaça de bezerros ate a desmama. In: SIMPOSIO SOBRE PECUARIA LEITEIRA, 3., Campinas, 1984 Anais, Campinas, Fund. Cargi11, p72-1401984.

COWAN, R.J.; SCHACKEL D. and DAUISON T.M. water intakes, milk yield and grazing behavior of friesian cows with restrided acess to water in a tropical enviroment. Australian journal of Agricultural and Animal Husbandry. parkvilie, 14(91): 190-5. Apr. 1978 .

CURTIS, S.E. \& HOUPT H. A. Animal ethology: It's a emergence in animal science. Journal of Animal Science, Champaign, 57 (1): 234-44, Jul. 1983.

DELLMEIR, G.R.;ERIEND T.H. \& GBUR E.E.Comparison of four methodos of calf confinament. II-Behaviour. Journal of Animal Science Champaign, 60 (5):1102-9, May, 1985.

EDWARDS, S.A. The behavior or dairy cows and their newborn calves in individual or group housing. Applied Animal Ethology. Amsterdam 10 (3): 191-8, May. 1983

EKELUND, K.; EVERITT B.; REIMER $T$. Feed manaqement in loose housing for dairy cows. A review of the literature and survey of nine herds. Raport, Institution för Lantvrukets Byggnadsteknik, Sveriges Lantbruksuniversited 16, $1981,74 \mathrm{p}$. Apud Dairy Science Abstracts, Earnham Royal 45 (1):8, Jan. 1983.

FRIEND, T.H.; DELLMEIER, G.R.; GBUR, E.E. Comparison of four methods of calf confinement. I Physiology. Journal of Animal 
Science, Champaign, 60 (5): 1095-101 1985.

FORDYCE, G.;GODDARD M.E.;SUFERT G.W. The measurement of temperament in cattle and the effect of experience and genotype. Proceedings of the Australian Society of Animal Production 14:329-32, 1982 Apud Animal Breeding Abstract, Edinburgh 51 (3):189 Mar. 1983.

FRASER, A.F. Farm Animal Behavior. Baltimore, The willians \& Wilkins, 1974. 196p.

GoMEs, I. Desaleitamento precoce de terneiros leiteiros usando-se como critério o consumo diário de concentrados. In: Reunião Anual da sociedade Brasileira de zootecnia, 20., Pelotas. Anais Viçosa, SBZ, 1983. p. 98.

GONYOU, H.W. \& STRICKLIN W.R. Eating behaviour of beef cattle groups fed from a single stall or trough. Applied Animal Ethology, Amsterdan, $7(2): 123-33$, Apr. 1981.

HAFEZ, E.S.E. The behaviour of domestic animals. 2.ed. Baltimore, The williams e wilkins 1969.647p.

HAFEZ, E.S.E. Physiology of behaviour. In: SWENSON, M.J. Dukes physiology of domestics animals. 8 ed. London, Cornell University Press, 1970 p.1052-81.

HOEKSTRA, J.A. \& JANSEN J. Statistical significance in comparative ethological experiments. Appleid Animal Behaviour Science, Amsterdan 16 (4):303-8, sep. 1986. 
JOHNSGARD, P. A. Animal behavior $2^{a}$ E. New Yorg, M.C. Brawr; 1973. 350p.

KERR, S.G.C. \& WOOD-GUSH D.G.M. The development of behaviour patterns and temperament in dairy heifers. Behavioral Processes 1987 (15) $1-6$.

KILGoUR, R. Animal behaviour in intensive systems and its relationship to disease an production. Australian Veterinary Journal, Parkville, 48( 3):94-8, Mar. 1972.

KILGOUR, R. The aplication of animal behavior and the humane care of farmanimals. Journal of Animal Science, Champaign $46(5): 1478-85$, May, 1978.

LEITLE, W. \& HARRISON R.D. Some observation on the behavior of dary cattle using cow-activated out-of-parlour concentrate dispenser. Journal of Dairy Research, New York, 51 (2):199-207. MaY, 1984 .

LUCCI, C.S.; FRETTAS, E.A.N. de;MOURA M.P.;FRANCA NETO B.G.; MENEZES J.B.O.X.; CAVALCANTI S.F. ObservaçZes sobre o hábito de vacas leiteiras em pastos de capim napier (Pennisetum purpureum) e de Capim Fino III - tempo de pastejo ruminação. Boletim da Indústria Animal, Nova Odessa 29 (1):59-65, jan, 1972.

LUCCI, C.S.; FREITAS, E.A.N. de; CAVALCANTI, S.F. ObservaçZes preliminares sobre o comportamento apresentado por bovinos da raca gir, alimentados com silagem ou feno. Boletim da Ináustria Animal, Nova Odessa, $26(2): 173-82$, mar, 1969. 
LUCCI C.S. Bovinos leiteiros Jovens. são Paulo, NOBEL, 1989. $371 \mathrm{p}$

MACHADO, L.C.P. O respeito aos principios etológicos no criacão de bovinos. Florianópolis, Universidade de Santa Catarina 1980. $38 \mathrm{p}$.

MANNING. A. An introducion to animal behavior. 2.ed Addison, Wesley Publishing, 1972. $145 p$.

MARTIN, P. 8 BATERSON, P. Measuring behaviour an introductory guide. Cambridge, Cambridge University press, $1986200 p$.

MURESAN, G.; VELEA, C.; DAUID, V. Behaviour of friesen dairy cows on pastures In Proceedings of the Romanian Simposium on the breeding manegement and disease of ruminants :279-288. 1982. Apud Herbage Abstracts 55 (9): 276. Sep. 1985.

NOLLER, C.H. Considerafoes fundamentais sobre os planos de desaleitamento. ESALQ - USP Piracicaba - SP - mimiografado 1961. 20 .

N.R.C. National Research Concil Nutrient requirement of dairy catle. Ed. 6 th, Whashington DC. National Academy Press. 1989. $157 \mathrm{p}$.

o'sulLIUAM, M. Measurement of grazing behaviour and herbage intake on two different grazing manegement systems for beef production. Grassland Beff Porduction, Dordrecht:141-150. 1984. Apuo Nerbage Abstracts. $55(1): 7$, Jan, 1985. 
POLLI, U.A. \& LOBATO J.F.P. Comportamento de bovinos de corte. I-Vacas de corte. In: Reunia Anual da SBZ, 21 , Belo Horizonte, Anais. Vicosa, 1984. pl09.

RADOSTITS,O.M. Treatment and control of neonatal diarrhea in calves. Journal of Dairy Science, Champaign, $58(3): 467-70$, Mar. 1975.

ROOIJEN, J.U. Preference tests, motivations, models and welfare. Applied Animal Etholo8y, Amsterdam, 11 (1):1-6, sep. 1983.

ROY, J.H.B. (a) The Calf - Manegement and feeding Vol I.Iondon Ilife Books, $1970 \cdot 183 p$.

ROY, J.H.B. (b) The calf-Nutricion and health. Vol II, London Iliffe Books, $1970164 p$.

SATO, S. Social licking pattern and it's relationships to social dominance and live weight gain in weaned calves. Applied Animal Behaviour Science, Amesteroam 12(1) 25-32, Jan. 1984.

SCHMISSEUR, W.E.; ALBRIGHT J.L. DILLON W.M.; KEHRBERG E.W.; MORRIS W.H.M. Animal behaviour responses to loose and free-stall housing. Journal of Dairy Science, Champaign, 49 (1) $102-4$, Jan. 1966

SCHAW, R.A. A time-controlled feeding system for catte. Animal Production, Edinburgh 27(3):277-84, Dec. 1978 .

STEPHENS, O.B. Studies on effect of social environment on the behaviour and orowth rates of artificially reared britsh friesen male calves. Animal Production, Edinburg, 18(1) 23-34, Eeb. 1974. 
STOCKDALE, C.R. \& KING K. R. A note on some of the factors that affect the water consuption of lactating dairy cows at pasture. Animal Production, Edinburgh, $36(2): 303-6$, Apr. 1983.

STRICKLIN, W.R.; C.E. HEISLER and L.L.WILSON Heritability of Temperament in Beef Cattle. Journal of Animal Science Champaign, 51 (1): 1-20. Jul. 1980.

UERGA, M.; PAUESI M. ; CERUTTI F. Behaviour and performance of veal calves under different stabling conditions. Anr. Zootechynies, Versailles, $34(3): 247-56$, sep. 1985.

WARNICK,U.D.; ARAVE,C.W.; MICKELSEN, C.H. Effects of group, individual, and isolated rearing of calves on weight gain ano behaviour. Journal of Dairy Science, Champaign, $60(6) ; 947-53$, Jun. 1977.

WEBSTER, A.J.F.; SAUILLE, C.;CHURCH, B.M.;GNANASAKTHY, A.; MOSS, R. The effect of different rearing systems on the development of calf behaviour. British Veterinary Journal, London, 141 (3): 249-64, May/Jun. 1985. 


\section{APENDICE}

Planilha de campo, utilizada para anotar as atividades desenvolvidas pelos animais durante as 24 horas. Foi utilizada uma planilha por hora de observacio. 


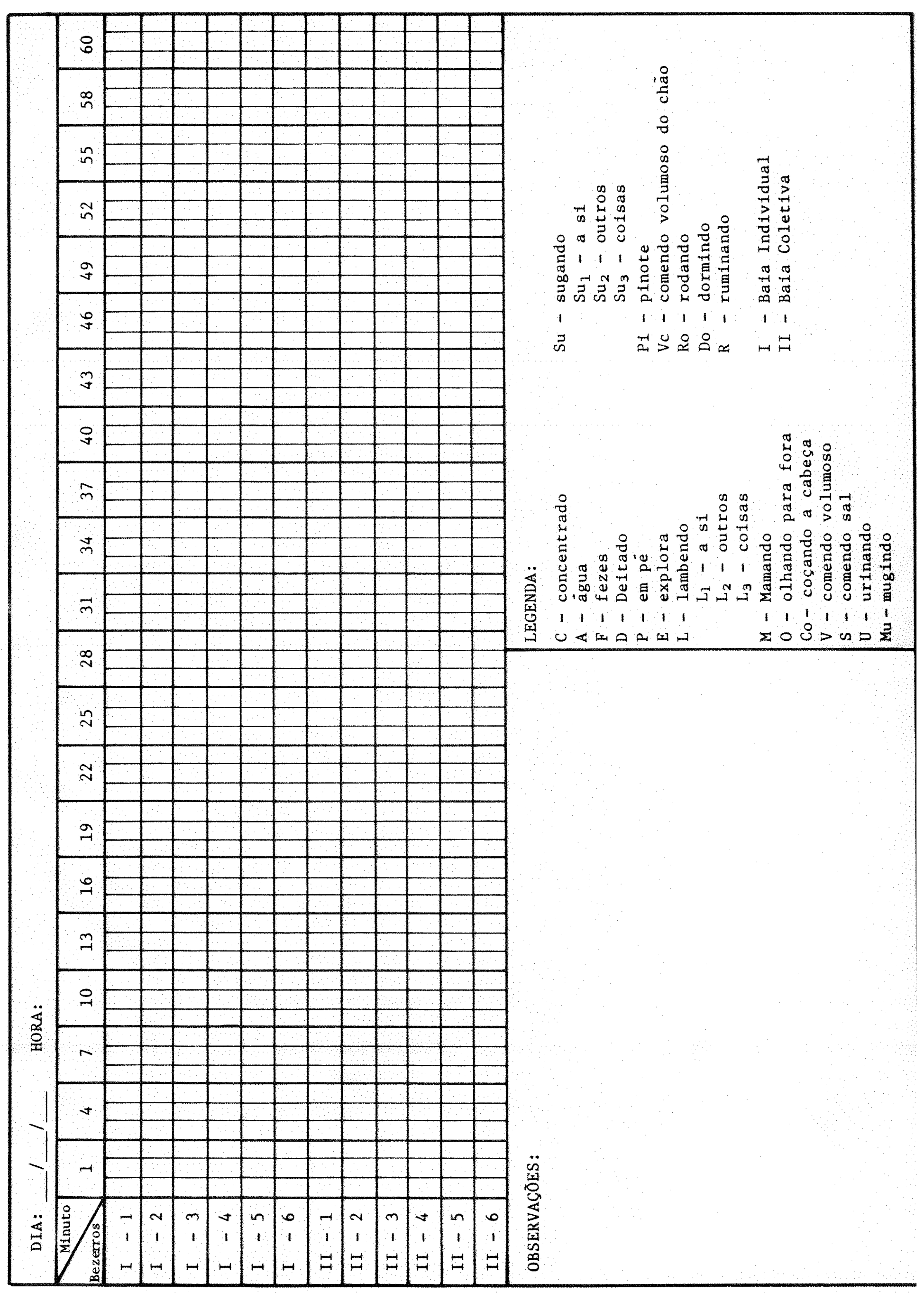

